\title{
New carnivoraforms (Mammalia) from the middle Eocene of California, USA, and comments on the taxonomic status of 'Miacis' gracilis
}

\author{
Susumu Tomiya
}

\begin{abstract}
The middle Eocene constitutes an important period for understanding the early evolution of carnivoraforms and the origin of crown-group carnivorans. Here I describe two new genera of carnivoraforms from the Uintan North American Land Mammal Age of southern California, and report hitherto-undescribed specimens of Procynodictis progressus, 'Miacis' gracilis, 'Miacis' hookwayi, and two undeterminate taxa to bridge some of the gaps in taxonomic knowledge. Specifically, the fossil materials described here support the placement of $P$. vulpiceps and $P$. progressus in the same genus but suggest their distinct identities at the species level. Similarly, 'M.' gracilis, which has been synonymized with $P$. vulpiceps by some authors, is considered a separate species from both $P$. vulpiceps and $P$. progressus. A minimum of 11 carnivoraform taxa are recognized in the middle Eocene of southern California, including nine from the late Uintan to the earliest Duchesnean (ca. 43-41 Ma ago). Of the latter, at least six taxa are apparently endemic to this region, thus conforming to the high provinciality of North American mammalian faunas during this time. In addition to the carnivoraforms, four taxa of creodonts and a mesonychid are known. The notably high taxonomic richness of middle-Eocene mammalian carnivores in southern California is associated with high diversity of non-carnivorous mammals known from there; this pattern agrees with the correlation between mammalian predator and prey diversity that has previously been observed at various spatiotemporal scales. The stratigraphic distributions of the lateUintan taxa reported here are consistent with the recently revised ages of vertebrate assemblages from the Sespe Formation of Ventura County, California, in the parsimonious sense.
\end{abstract}

Susumu Tomiya. Museum of Paleontology, Museum of Vertebrate Zoology, and Department of Integrative Biology, University of California, Berkeley, California 94720 USA stomiya@berkeley.edu

Keywords: Carnivoramorpha; Carnivoraformes; Eocene; California; new genus

Tomiya, Susumu. 2013. New carnivoraforms (Mammalia) from the middle Eocene of California, USA, and comments on the taxonomic status of 'Miacis' gracilis, Palaeontologia Electronica Vol. 16, Issue 2; 14A; 29p; palaeo-electronica.org/content/2013/435-eocene-carnivoraforms 


\section{INTRODUCTION}

Recent molecular phylogenetic and paleontological studies have suggested the middle Eocene (ca. 49-37 Ma ago) to be a critical period in the early evolution of the mammalian order Carnivora (e.g., Eizirik et al., 2010; Tomiya, 2011). While the occurrences of middle-Eocene carnivoraforms in coastal southern California have long been recognized (Golz and Lillegraven, 1977; Walsh, 1996), few studies since the early twentieth century have provided descriptions of the known specimens or addressed their taxonomic statuses in detail (Stock, 1934, 1935; Wesley and Flynn, 2003; Tomiya, 2011). Here, I report new taxa and significant new records of presently recognized taxa from Ventura and San Diego Counties (Figure 1.1). Because the currently available fossil materials are insufficient for rigorous cladistic analysis, the aim of this paper is to highlight the diversity of middleEocene carnivoraforms from southern California and to clarify taxonomic statuses of Procynodictis and 'Miacis' gracilis-two taxa of key importance for elucidating the carnivoran origin (cf. Wortman and Matthew, 1899; Clark, 1939; Tomiya, 2011; Spaulding and Flynn, 2012)-based on hithertoundescribed specimens. The present study is part of an ongoing effort to assess the diversity dynamics of carnivorous mammals in this region during the Uintan and Duchesnean North American Land Mammal Ages (Tomiya, 2012).

The fossil-bearing localities reported here are predominantly associated with land development and urban construction sites; as such, many of the localities were destroyed subsequent to the recovery of fossils. Inferences of locality ages are based primarily on the regional mammalian biostratigraphy and lithostratigraphy, which have been tied to a limited number of (and sometimes equivocal) magnetostratigraphic and radioisotopic dates (Walsh et al., 1996). Consequently, much uncertainty remains with respect to the precise temporal relationships of geographically isolated formations within coastal southern California as well as the temporal relationship between this region and the Western Interior (cf. Walsh, 1996; Walsh et al., 1996; Prothero, 2001; Lander, 2011, appendix C; Kelly et al., 2012). The Poway fauna of the Friars Formation, which was assigned to the informal biochron Ui1b by Gunnell et al. (2009), is significant because the North American mammalian fossil record for the earliest Uintan NALMA is sparse in the Western Interior (Gunnell et al., 2009).

\section{Abbreviations}

Institutional Abbreviations. AMNH, American Museum of Natural History, New York, New York, USA; CM, Carnegie Museum of Natural History, Pittsburgh, Pennsylvania, USA; LACM, Los Angeles County Museum of Natural History, Los Angeles, California, USA; SDSNH, San Diego Natural History Museum, San Diego, California, USA; UCMP, University of California Museum of Paleontology, Berkeley, California, USA.

Other Abbreviations. NALMA, North American Land Mammal Ages.

\section{MATERIALS AND METHODS}

The fossil materials of new taxa described in this paper are housed at the Los Angeles County Museum of Natural History (LACM), the San Diego Natural History Museum (SDSNH), and the University of California Museum of Paleontology (UCMP). The anatomical terminology generally follows $\mathrm{Van}$ Valen (1966), Flynn and Galiano (1982), and Heinrich et al. (2008) for dentition and Wang and Tedford (1994) for basicranium. Dental and mandibular measurements (see Gingerich, 1983, figure 1 for illustration of pertinent dimensions) were taken with digital calipers with the accuracy of $0.02 \mathrm{~mm}$ and a measuring microscope (comparable to Ehrenreich Photo-Optical Industries Shopscope) to the nearest $0.01 \mathrm{~mm}$. Angles were measured on digital photographs using the program tpsDIG2 (Rohlf, 2006).

\section{Nomenclatural Acts}

This published work and the nomenclatural acts it contains have been registered in ZooBank, the proposed online registration system for the International Commission on Zoological Nomenclature. The ZooBank LSIDs (Life Science Identifiers) can be resolved and the associated information viewed through any standard web browser by appending the LSID to the prefix "zoobank.org/". The LSID for this publication is: urn:Isid:zoobank.org:pub:141E815B-15DA-407C-A07F51C0EE3351AB.

\section{SYSTEMATIC PALEONTOLOGY}

Class MAMMALIA sensu Rowe, 1988

Unranked clade CARNIVORAMORPHA sensu Bryant, 1996

Unranked clade CARNIVORAFORMES Flynn, Finarelli, and Spaulding, 2010

Genus CERUTTIA n. gen. urn:Isid:zoobank.org:act:C0062BE9-014C-42AE- 


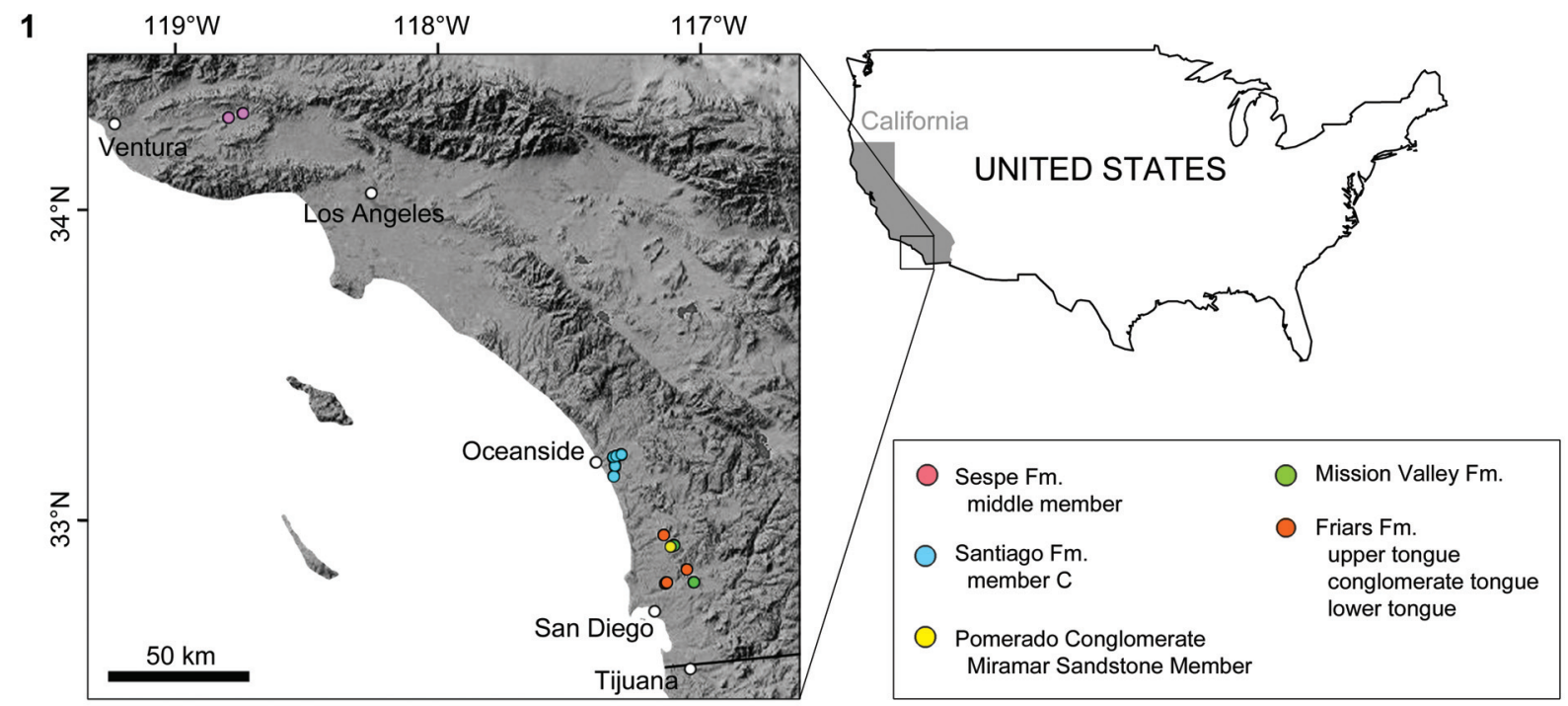

2

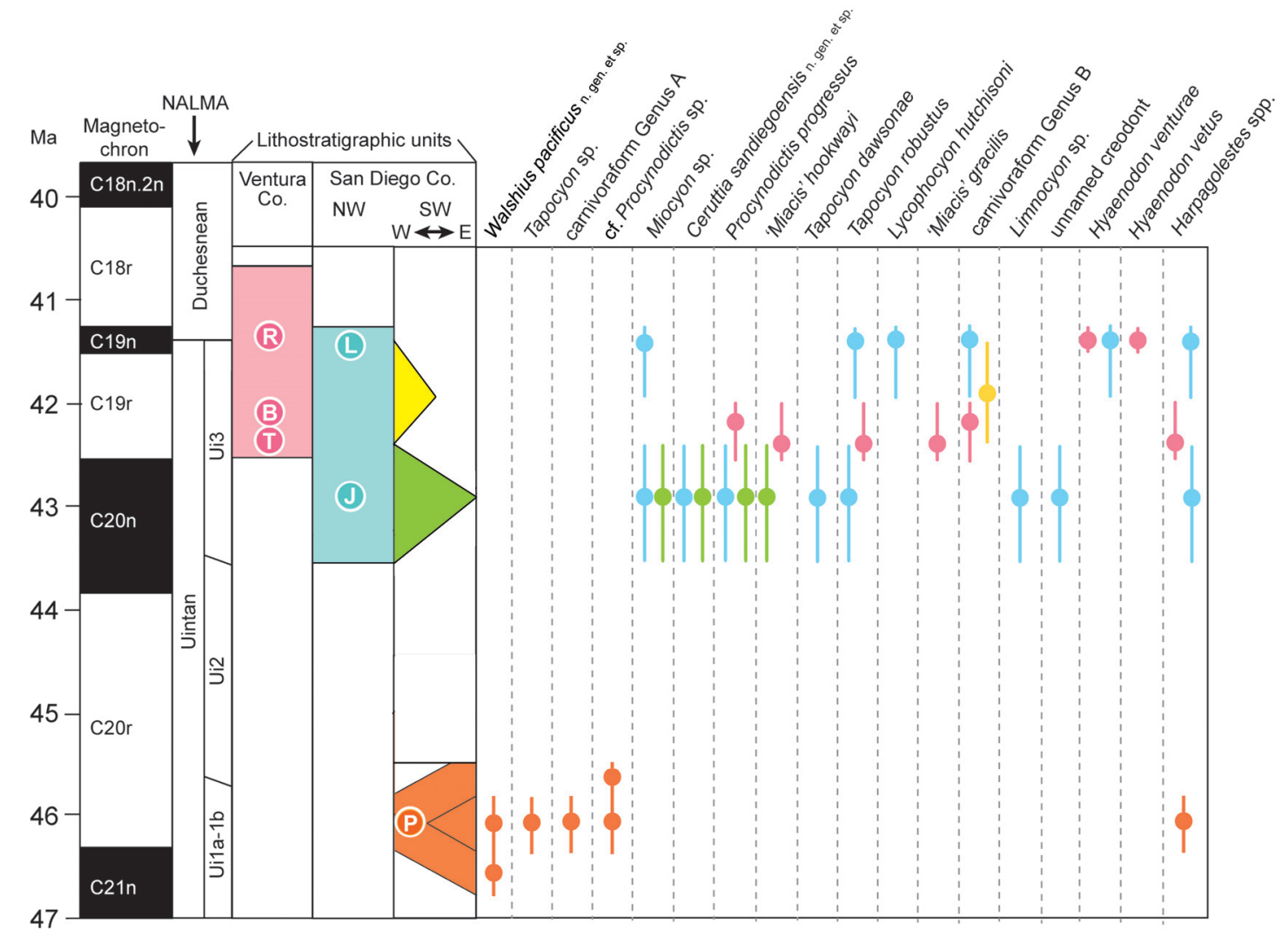

FIGURE 1. Spatiotemporal distributions of middle-Eocene carnivoraforms in southern California. 1, Map of localities that have yielded carnivoraforms. 2, Stratigraphic distributions of mammalian carnivores. See legend for color coding of various geologic formations. Temporal correlation of fossil assemblages, lithologic units, and magnetochrons follows Walsh (1996), Walsh et al. (1996), Mihlbachler and Deméré (2009), and Kelly et al. (2012), and generally should not be regarded as precise above one million-year resolution (cf. Walsh, 1996). See Lander (2011) for alternative age assignments for Mission Valley Formation and local faunas of Brea Canyon, Tapo Canyon, and Jeff's Discovery site. Vertical lines represent minimum age uncertainties. Significant local faunas are indicated as follows: B, Brea Canyon; J, Jeff's Discovery; L, Laguna Riviera; P, Poway; R, Pearson Ranch; T, Tapo Canyon. Original map for Figure 1.1 generated by BerkeleyMapper (berkeleymapper.berkeley.edu/). 


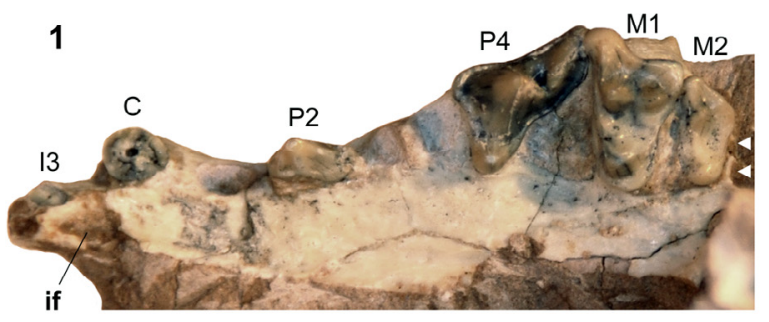

4
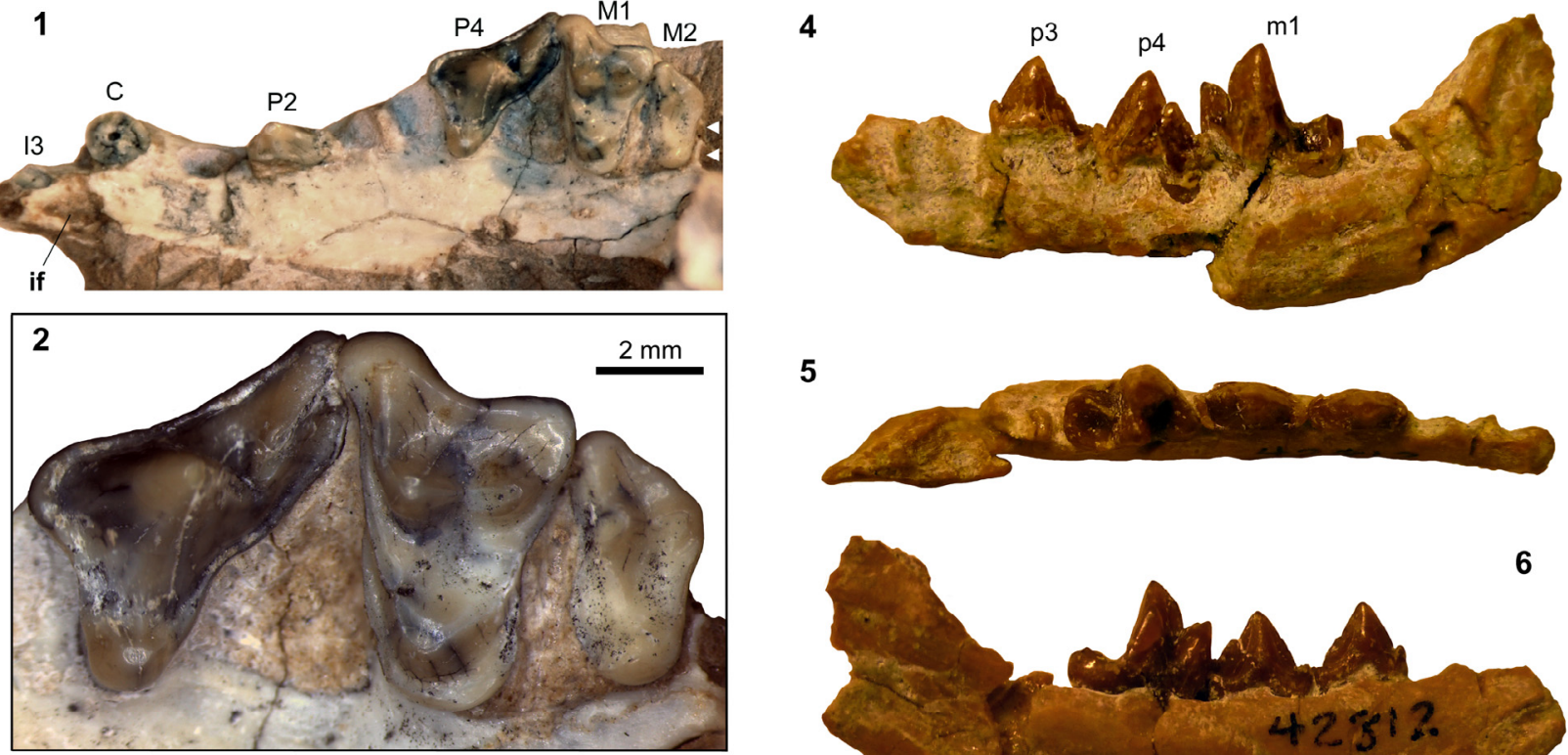

5
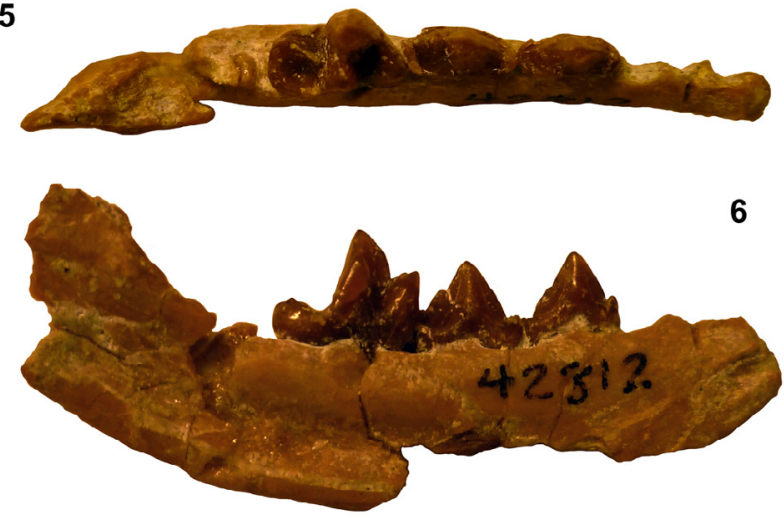

3

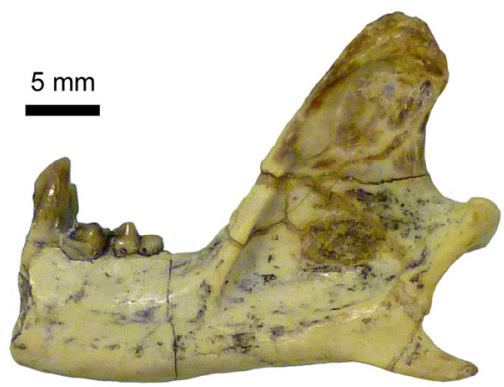

7
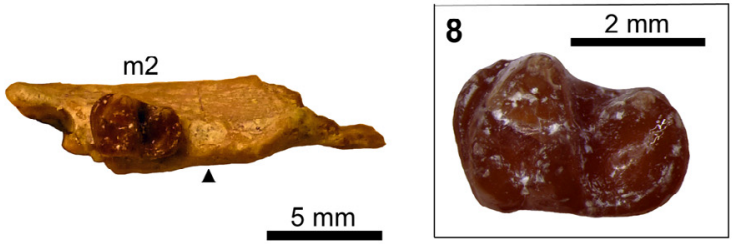

FIGURE 2. Dentition of Ceruttia sandiegoensis n. gen. et sp. Left premaxilla and maxilla of the holotype SDSNH 92504 in ventral view (1); left P4-M2 of SDSNH 92504 in occlusal view (2); left dentary fragment of SDSNH 92503 in labial view (3); left dentary fragment of SDSNH 42812 in labial (4), occlusal (5), and lingual (6) views; right dentary fragment (7) and right $\mathrm{m} 2$ (8) of SDSNH 42812 in occlusal view. Two white triangles in Figure 2.1 point to possible alveoli for M3. Black triangle in Figure 2.5 points to alveolus for m3. Same scale bar applies to Figure 2.1 and 2.4-2.7. Abbreviation: if, incisor foramen.

\section{F4-948D6F7FA242}

Figures 2, 3

Diagnosis. As for type species.

Distribution. As for type species.

Etymology. Generic name after Richard A. Cerutti of the San Diego Natural History Museum and in honor of his contribution to the growth of the vertebrate paleontology collection at the museum.

Ceruttia sandiegoensis n. sp. urn:Isid:zoobank.org:act:3CC5B1F9-10E0-405F-

\section{B3EB-07B5FFCEB4AB}

Figures 2, 3

Holotype. SDSNH 92504, cranial fragments including right maxilla with $\mathrm{P} 4$ and $\mathrm{M} 1$, left premaxilla with broken 13 , left maxilla with broken C, P2, and P4-M2.
Holotype Locality. SDSNH locality 4888, State Road 125 North (Unit II, Mid Brown Siltstone), Mission Valley Formation, El Cajon, San Diego County, California, USA.

Referred Specimens. SDSNH locality 3276, Jeff's Discovery, Santiago Formation, member C, Oceanside, San Diego County, California, USA: SDSNH 43657, right $\mathrm{m} 2$; SDSNH 48180, left dentary fragment with $\mathrm{p} 2-4$.

SDSNH locality 3562, Jeff's Discovery, Santiago Formation, member C, Oceanside, San Diego County, California, USA: SDSNH 42811, left dentary fragment with $\mathrm{p} 2, \mathrm{p} 3, \mathrm{~m} 1$, and $\mathrm{m} 2$; SDSNH 42812, right and left maxillary fragments with M1 and $M 2$, right dentary fragment with $\mathrm{m} 2$, left dentary fragment with $\mathrm{p3}-\mathrm{m} 1$ (upper molars embedded in greenish gray sandstone matrix); SDSNH 

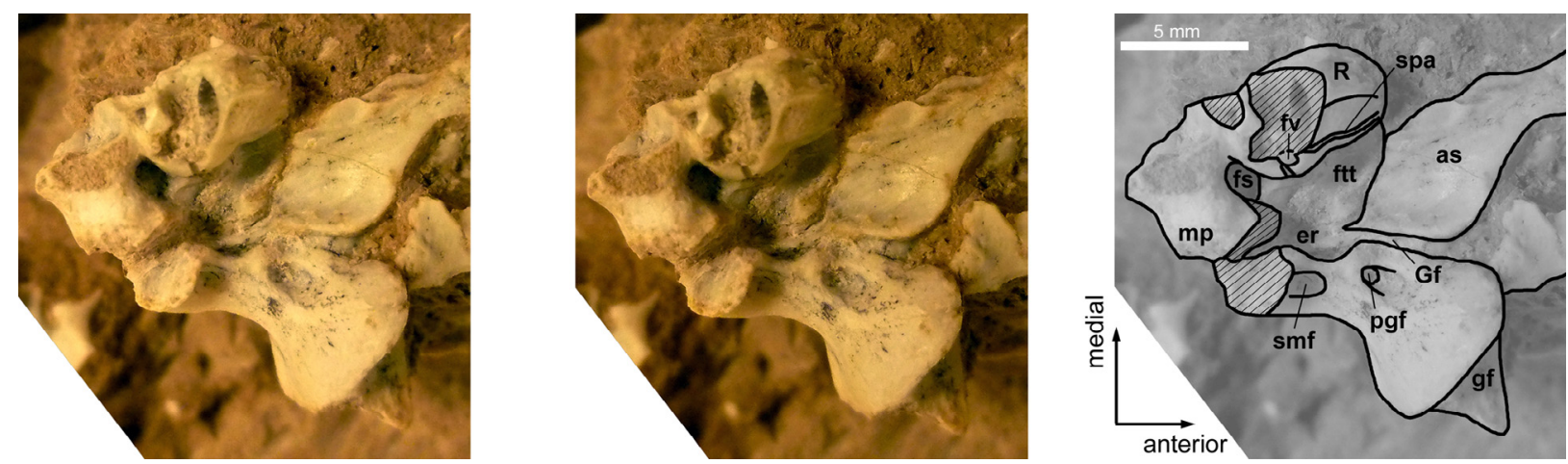

FIGURE 3. Left auditory region (SDSNH 92504) of Ceruttia sandiegoensis n. gen. et sp. Abbreviations: as, alisphenoid; er, epitympanic recess; fs, fossa for stapedius muscle; ftt, fossa for tensor tympani; fv, fenestra vestibuli; gf, glenoid fossa; Gf, Glaserian fissure; $\mathbf{m p}$, mastoid process; pgf, postglenoid fossa; $\mathbf{R}$, rugose area on petrosal promontorium; smf, suprameatal fossa; spa, sulcus for stapedius artery.

47192, left P4; SDSNH 48134, right dentary fragment with $\mathrm{p} 3-\mathrm{m} 1$.

SDSNH locality 3564, Jeff's Discovery, Santiago Formation, member C, Oceanside, San Diego County, California, USA: SDSNH 46804, left M1; SDSNH 47575, left M2; SDSNH 48121, right $\mathrm{m} 2$; SDSNH 52844, right M2 fragment; SDSNH 52968, right M2; SDSNH 54350, left M2; SDSNH 54945, left M1.

SDSNH locality 4888, State Road 125 North (Unit II, Mid Brown Siltstone), Mission Valley Formation, El Cajon, San Diego County, California, USA: SDSNH 92503, left dentary fragment with broken $\mathrm{m} 1$ and $\mathrm{m} 2$.

Distribution. Portions of the Mission Valley Formation and member C (Wilson, 1972) of the Santiago Formation, San Diego County, California, USA, probably corresponding to the biochron Ui3 of Uintan NALMA (cf. Walsh et al., 1996; Prothero, 2001; Robinson et al., 2004).

Etymology. Specific name in reference to San Diego County.

Diagnosis. Differs from: caniform carnivorans in relatively closed trigonid of $\mathrm{m} 1$; feliform carnivorans in relatively closed trigonid of $\mathrm{m} 1$, large talonid of $\mathrm{m} 1$, moderately large second molars relative to first molars, and presence of $\mathrm{m} 3$; viverravids in vestigial parastyle of $\mathrm{P} 4, \mathrm{~m} 2$ with short talonid, and presence of m3; 'Miacis' australis, 'Miacis' cognitus, 'Miacis' parvivorus, Miocyon, Oodectes, Palaearctonyx, Vassacyon, and Vulpavus in more elongate parastylar region of M1, greater anteroposterior constriction of lingual portion of $\mathrm{M} 1$, and smaller second molars relative to first molars; Xinyuictis in absence of cusp on labial ridge of $\mathrm{M} 1$ at ectoflexus, broader $\mathrm{M} 1$ lingual cingulum, proportionately lower trigonid cuspids of $\mathrm{m} 1$ and $\mathrm{m} 2$, and labiolingually wider talonid basins of $\mathrm{m} 1$ and $\mathrm{m} 2$; Uintacyon in clear separation of M1 postprotocrista from posterior lingual cingulum, more dorsal position of posterior accessory cuspid of $\mathrm{p} 4$, low trigonid of $\mathrm{m} 1$, and wider and deeper talonid basins of $\mathrm{m} 1$ and $\mathrm{m} 2$; Paroodectes in greater length than height of $\mathrm{m} 1$ and smaller second molars relative to first molars $(\mathrm{m} 2 \mathrm{~L} / \mathrm{m} 1 \mathrm{~L}=0.58$ in SDSNH 42812 compared to $\mathrm{m} 2 \mathrm{~L} / \mathrm{m} 1 \mathrm{~L} \approx 0.9$ in a cast (UCMP 123612) of holotype of $P$. feisti); 'Miacis' deutschi, 'Miacis' exiguus, 'Miacis' latouri, and Gracilocyon in greater labial extension of M1 parastylar region relative to metastylar region and shallower angle of ectoflexus (approximately $135^{\circ}$ in holotype); 'Miacis' petilus and 'Miacis' latidens in presence of dorsally-positioned posterior accessory cusp on $\mathrm{p} 4$ and more open trigonid of $\mathrm{m} 1$; 'Miacis' medius in smaller second molars relative to first molars and greater anteroposterior constriction of lingual portion of M1; 'Miacis' hargeri, 'Miacis' sylvestris, and 'Miacis' washakius in posteriorly wider talonid of $\mathrm{m} 1$ and more closed trigonids of $\mathrm{m} 1$ and $\mathrm{m} 2$; 'Miacis' invictus in greater anteroposterior compression of M1; Eogale and 'Miacis' igniculus in more conical and dorsally-positioned posterior accessory cuspid of p4; 'Miacis' hookwayi in more closed trigonid of $\mathrm{m} 1$, narrower $\mathrm{m} 1$ talonid relative to trigonid, and steeper angle between cristids obliqua and anteroposterior axes of $\mathrm{m} 1$ and $\mathrm{m} 2$; Dawsonicyon in absence of hypocone on M1 and $\mathrm{M} 2$, more dorsally positioned posterior accessory cuspid of $\mathrm{p} 4$, absence of deep posterior basin on p4, and steeper angle between cristids obliqua and anteroposterior axes of $\mathrm{m} 1$ and $\mathrm{m} 2$; Paramiacis in smaller second molars relative to first molars; Quercygale in better-developed lingual cingulum of $\mathrm{M} 1$ and larger talonid of $\mathrm{m} 1$ relative to trigonid; 
Tapocyon in less elongate parastylar region of M1, and larger second molars relative to first molars; 'Miacis' gracilis, 'Miacis' lushiensis, and Procynodictis in more conical posterior accessory cuspid of $\mathrm{p} 4$, and more closed trigonid of $\mathrm{m} 1$; 'Miacis' uintensis in more conical and dorsally-positioned posterior accessory cuspid of $\mathrm{p} 4$ and greater length of $\mathrm{m} 1$ compared to $\mathrm{p} 4$; other species of Miacis in posterior accessory cuspid of $\mathrm{p} 4$ located on posterior slope of main cuspid and smaller second molars relative to first molars ((M2Lx M2W)/(M1L x M1W) $=0.3-0.4$ in known specimens); Procynodictis in absence of preparacrista on P4, less elongate parastylar region of $\mathrm{M} 1$, and similar widths of anterior and posterior lingual cingula of $\mathrm{M} 1$ in occlusal view.

Further differs from: Gracilocyon in more dorsal position of posterior accessory cuspid of p4, greater length of $m 1$ relative to its height, and more reduced trigonid cuspids of m2; Miacis parvivorus in lack of hypocone on M1 and presence of welldeveloped posterior accessory cuspid on p4; 'Miacis' gracilis in more anterior orientation of labial extremity of M1 parastylar region and greater anteroposterior constriction of lingual portion of M2; 'Miacis' washakius in greater anteroposterior constriction of lingual portion of M1.

Description. Unless otherwise noted, the following descriptions of upper dentition and cranium are based on the holotype, and the description of the lower dentition pertains to SDSNH 42812. The latter specimen is referred to Ceruttia sandiegoensis based on its upper dentition (M1 and M2) that does not differ significantly from that of the holotype. All dental dimensions are reported in Table 1.

In the holotype, the transversely compressed left $I 3$ and the left upper canine are both broken at the bases of their crowns (Figure 2.1). The narrow $\mathrm{P} 2$ has a simple triangular profile; the anterior cingulum is a diminutive bulge, and the posterior cingulum is likewise small. No cuspule is present on either the anterior or posterior cingulum of the P2. The P4 is surrounded by a clearly defined cingulum except around the protocone (Figure 2.2). The small protocone has less than one-third the height of paracone and is located slightly anterior to the level of paracone. The anterior labial cingulum forms a very small bulge, but a parastyle as a distinct cuspule is lacking. A clearly defined preparacrista is absent. A deep carnassial notch separates the paracone and metastylar blade.

The M1 is anteroposteriorly compressed (Figure 2.2). The parastylar region is moderately elongate in the anterolabial direction such that the distance between the paracone and the labial margin of the tooth roughly equals the distance between the paracone and the protocone. The paracone is substantially taller than the metacone. The labial segment of preparacrista forms a sharp ridge that extends more or less straight in the labial direction. Anterolabial to this blade, the parastylar region terminates with a somewhat bulbous hook formed by the anterior labial cingulum. A wide stylar shelf is present labial to the paracone and metacone, and its labial border is demarcated by a well-defined ridge. In occlusal view, the ectoflexus has a wide $V$-shape. The paraconule is well-developed and is separated from the protocone by a small notch. The tooth apparently lacks a metaconule. The height of the protocone is subequal to that of the paracone. The lingual cingulum maintains roughly the same width around the protocone.

Similar to the M1, the M2 is anteroposteriorly compressed and has a labially extended parastylar region (Figure 2.2). The labial border of the tooth is essentially straight. In SDSNH 42812, the trenchant labial segment of preparacrista is directed anterolabially toward the margin of the tooth. The small paracone and metacone of SDSNH 52968 are subequal in size and closely positioned. The low protocone is nearly confluent with the thick and somewhat bulbous lingual cingulum. No paraconule or metaconule is present. Although none of the currently known specimens preserves a M3, two transversely positioned, posteriorly open holes are present at the posterior end of each maxilla in the holotype (white triangles in Figure 2.1), possibly representing the alveoli for the M3.

SDSNH 92503, a dentary fragment known from the same locality as the holotype SDSNH 92504, preserves the portion of mandible posterior to the $\mathrm{m} 1$ trigonid (Figure 2.3). As in SDSNH 42812, the horizontal ramus below the $\mathrm{m} 1$ is slightly deeper than the height of $\mathrm{m} 1$ protoconid. The masseteric fossa is of moderate depth, and the angular process projects posteriorly roughly to the same level as the mandibular condyle. Behind the single alveolus for $\mathrm{m} 3$, the ascending ramus rises at an angle of roughly $60^{\circ}$ and forms an anteroposteriorly rather narrow coronoid process with a rounded dorsal margin.

The p2 of SDSNH 42811 (not figured) is transversely compressed and lacks well-developed cuspulids on its anterior and posterior cingulids. A sharp ridge is present on the posterior slope of the main cuspid. The p3 (Figure 2.4-6) has a small cuspulid on the anterior cingulid, but no cuspulid on 
TABLE 1. Dental dimensions of Ceruttia sandiegoensis, n. gen. et sp. Measurements in millimeters. Where applicable, the arithmetic mean of measurements for the right and left teeth is reported. ${ }^{1}$ Measured at the base of crown.

\begin{tabular}{|c|c|c|c|c|c|c|c|c|c|}
\hline & $\begin{array}{c}\text { SDSNH } \\
92504\end{array}$ & $\begin{array}{c}\text { SDSNH } \\
42812\end{array}$ & $\begin{array}{c}\text { SDSNH } \\
46804\end{array}$ & $\begin{array}{c}\text { SDSNH } \\
52968\end{array}$ & $\begin{array}{c}\text { SDSNH } \\
54350\end{array}$ & $\begin{array}{c}\text { SDSNH } \\
54945\end{array}$ & $\begin{array}{c}\text { SDSNH } \\
42811\end{array}$ & $\begin{array}{c}\text { SDSNH } \\
43657\end{array}$ & $\begin{array}{c}\text { SDSNH } \\
92503\end{array}$ \\
\hline I3L1 & 2.02 & & & & & & & & \\
\hline $13 W^{1}$ & 1.15 & & & & & & & & \\
\hline $\mathrm{CL}^{1}$ & 3.23 & & & & & & & & \\
\hline $\mathrm{CW}^{1}$ & 2.54 & & & & & & & & \\
\hline P2L & 3.85 & & & & & & & & \\
\hline P2W & 1.69 & & & & & & & & \\
\hline P4L & 6.57 & & & & & & & & \\
\hline P4W & 4.78 & & & & & & & & \\
\hline M1L & 4.41 & 4.38 & 4.62 & & & 4.85 & & & \\
\hline M1W & 7.06 & 6.81 & na & & & 7.24 & & & \\
\hline M2L & $\sim 2.5$ & 2.18 & & 2.67 & 2.14 & & & & \\
\hline M2W & 4.70 & 4.33 & & 5 & 4.00 & & & & \\
\hline p3L & & 4.37 & & & & & & & \\
\hline p3W & & 1.99 & & & & & & & \\
\hline p4L & & 5.31 & & & & & & & \\
\hline p4W & & 2.26 & & & & & & & \\
\hline $\mathrm{m} 1 \mathrm{~L}$ & & 6.23 & & & & & 5.97 & & na \\
\hline $\mathrm{m} 1 \mathrm{~W}$ & & 3.68 & & & & & na & & na \\
\hline $\begin{array}{l}\mathrm{m} 1 \\
\text { trigonid } \\
\text { length }\end{array}$ & & 3.92 & & & & & & & na \\
\hline $\begin{array}{l}\mathrm{m} 1 \\
\text { trigonid } \\
\text { height }\end{array}$ & & $\sim 5.2$ & & & & & & & $\sim 6.2$ \\
\hline $\mathrm{m} 2 \mathrm{~L}$ & & 3.61 & & & & & & 3.42 & 3.62 \\
\hline $\mathrm{m} 2 \mathrm{~W}$ & & 2.52 & & & & & & 2.57 & 2.89 \\
\hline $\begin{array}{l}\text { mandibul } \\
\text { ar depth }\end{array}$ & & $\sim 6.9$ & & & & & & & 8.44 \\
\hline
\end{tabular}

the posterior cingulid. A raised ridge is present on the posterior slope of the main cuspid that may represent an incipient posterior accessory cuspid. The overall morphology of the p4 (Figure 2.4-6) is similar to that of the p3. The p4 is slightly longer and wider than the p3, but the two teeth are subequal in height. A small notch separates the main cuspid from the posterior accessory cuspid. The latter is somewhat conical in form and is more prominent than the one on the p3. The rather dorsal position of this accessory cuspid on the steeply descending posterior slope of main cuspid appears to be a peculiar feature of Ceruttia sandiegoensis.

The $\mathrm{m} 1$ has a relatively low trigonid (Table 1). The paraconid and metaconid are subequal in size. The trigonid is more open (Figure 2.5) than is typical among early Eocene carnivoraforms. The tal- onid basin is moderately deep. The trenchant cristid obliqua in occlusal view runs parallel to the anterior wall of trigonid and bears a small hypoconid at its posterior end. The entoconid is a small bulge on the posterolingual portion of the ridge that encircles the talonid basin and is located posterior to a small cuspulid on the same ridge.

The $\mathrm{m} 2$ is approximately $40 \%$ shorter than the m1 (Figure 2.7, Table 1). The protoconid, paraconid, and metaconid are subequal in height. The trigonid has a closed appearance in occlusal view because of the proximity of the paraconid and metaconid (Figure 2.8). As in the $\mathrm{m} 1$, the talonid basin is encircled by a clearly defined ridge; the hypoconid and entoconid are not discernible as individual cuspids. The anterior labial cingulid is well-defined. Although none of the currently known 
specimens preserves the $\mathrm{m} 3$, an alveolus for this tooth ( 1.4 $\mathrm{mm}$ in length) is present on SDSNH 42812 (black triangle in Figure 2.7).

The shape of maxilla suggests a narrow rostrum. The lateral margin of infraorbital foramen in lateral view is positioned above the P3. Most of the incisive foramen is located anterior to the upper canine, although its precise extent is unclear ("if" in Figure 2.1).

The auditory region (Figure 3 ) is characterized by: 1) a well-ossified fossa for tensor tympani ("ftt" in Figure 3); 2) a shallow suprameatal fossa on the squamosal ("smf" in Figure 3) located lateral to the dorsally deep epitympanic recess; 3 ) petrosal promontorium with a round anterior end and a somewhat rugose medial surface ("R" in Figure 3) presumably for the attachment of an entotympanic; and 4) presence of a sulcus on the lateral surface of promontorium for the promontory artery ("spa" in Figure 3). The fossa for stapedius muscle is deep and well-defined ("fs" in Figure 3). A portion of the mastoid that bears the mastoid tubercle has apparently broken off in the holotype. The surface of the petrosal promontorium surrounding the fenestra cochlea is likewise damaged by breakage, so the precise shapes and positions of the fenestra cochlea and fenestra vestibuli are unclear. There is a small, shallow depression on the squamosal immediately medial to the postglenoid foramen (and partly overlapping with the Glaserian fissure) that may represent an attachment site for the ectotympanic. However, none of the currently known specimens preserves an ossified element of the auditory bulla.

Remarks. The dentition of Ceruttia sandiegoensis resembles those of the Bridgerian carnivoraforms 'Miacis' sylvestris and ' $M$.' hargeri in the forms of upper molars and lower premolars, and is less similar to that of Miacis parvivorus. Because there is little cladistic support for assignment of either ' $M$.' sylvestris or ' $M$.' hargeri to the genus Miacis (Tomiya, 2011; Spaulding and Flynn, 2012), assignment of the new species described here to Miacis would be best avoided despite its possible phylogenetic proximity to 'M.' sylvestris and ' $M$.' hargeri.

The morphology of parastylar region of $\mathrm{M} 1$ is noticeably variable among specimens. Specifically, the holotype from the Mission Valley Formation shows greater labial elongation and a more prominent "hook" formed by the anterior portion of labial cingulum compared to referred specimens from Jeff's Discovery sites of the Santiago Formation. Nevertheless, since the overall dental mor- phology is reasonably uniform across known specimens and the localities are likely of similar ages (cf. Walsh, 1996), the morphological variation in $\mathrm{M} 1$ is here considered to be intraspecific in nature.

The morphological characteristics of the auditory region are comparable to those of Miacis parvivorus and 'Miacis' sylvestris (Wang and Tedford, 1994, figures 1, 3). The apparent lack of ossified auditory bulla, transpromontorial passage of internal carotid artery, and relatively rounded (rather than dorsoventrally flattened) anterior portion of promontorium represent more primitive conditions than in basal members of the crown-group carnivorans (cf. Tomiya, 2011).

Genus WALSHIUS n. gen. urn:Isid:zoobank.org:act:FC50E6C0-BDF0-4085A05D-14DC7ADFBD80

Figure 4.1, 4.2

Diagnosis. As for type species.

Distribution. As for type species.

Etymology. Generic name after the late Stephen L. Walsh of the San Diego Natural History Museum and in honor of his contribution to the study of Eocene mammals from the San Diego area.

Walshius pacificus n. sp. urn:Isid:zoobank.org:act:DB35CBFE-BEBE-4B79B03C-9C0AAF6AECE2

Figure 4.1, 4.2

Holotype. SDSNH 46197, right maxillary fragment with broken P3, P4-M2.

Holotype Locality. SDSNH locality 3655 , State Route 52 East Site 5, Friars Formation (lower tongue), San Diego, San Diego County, California, USA.

Referred Specimen. SDSNH locality 4165, County Water Authority Pipeline 5, Friars Formation (upper tongue), San Diego, San Diego County, California, USA: SDSNH 62150, right maxillary fragment with P2-P4.

Distribution. Portions of the Friars Formation, San Diego County, California, USA, corresponding to the biochron Ui1b of Uintan NALMA (cf. Walsh et al., 1996; Gunnell et al., 2009).

Etymology. Specific name in reference to its occurrence on the Pacific coast of North America.

Diagnosis. Differs from: viverravids in vestigial parastyle of P4; Ceruttia, Dawsonicyon, Gracilocyon, Miacis (including those species with questionable affinity with $M$. parvivorus), Miocyon, Oodectes, Paramiacis, Palaearctonyx, Uintacyon, Vassacyon, and Vulpavus in greater labial elongation of M1 parastylar region (transverse distance to 
1
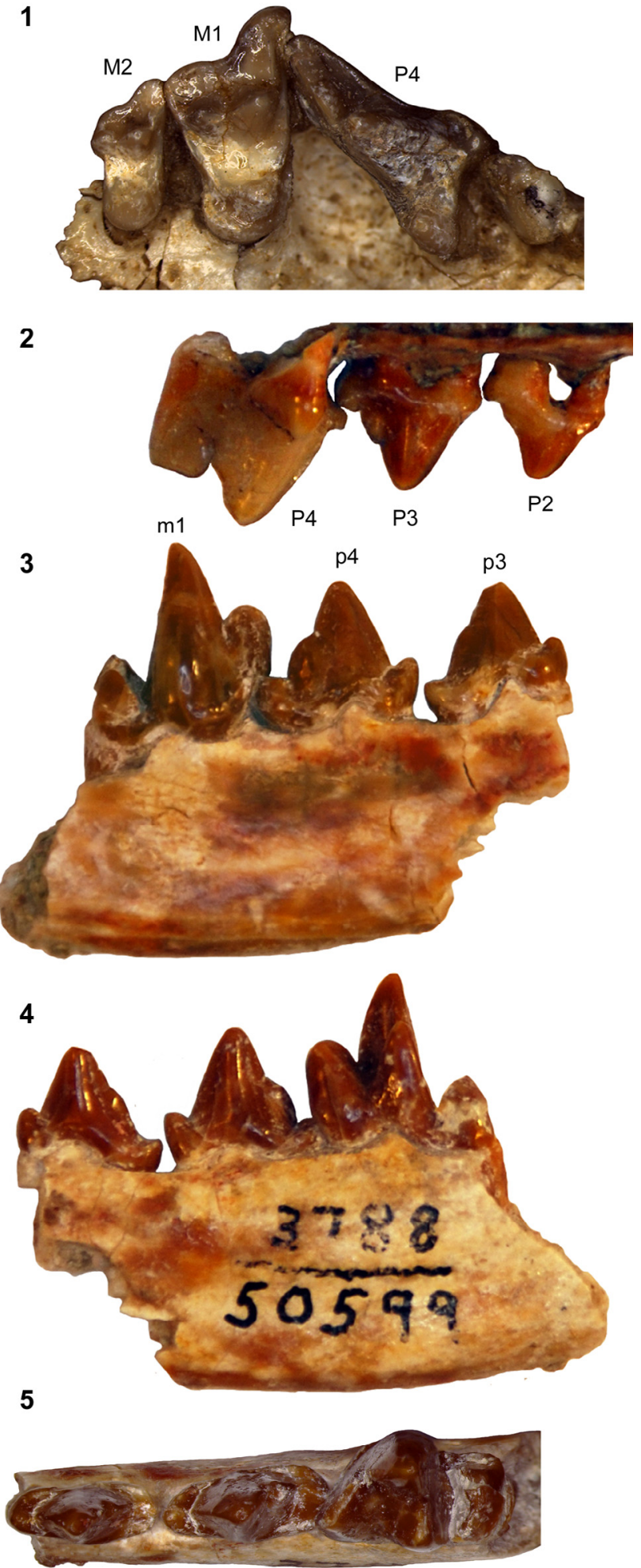

$5 \mathrm{~mm}$

FIGURE 4. Dentition of Walshius pacificus n. gen. et sp. Right maxillary fragment of SDSNH 46197 in occlusal view (1); right maxillary fragment of SDSNH 62150 in lingual view (2, inverted); right dentary fragment of SDSNH 50599 (cf. W. pacificus) in labial (3), lingual (4), and occlusal (5) views. 
TABLE 2. Dental dimensions of Walshius pacificus, n. gen et sp. Measurements in millimeters. SDSNH 50599 is tentatively referred to $W$. pacificus. Where applicable, the arithmetic mean of measurements for the right and left teeth is reported.

\begin{tabular}{|c|c|c|c|}
\hline & SDSNH 46197 & SDSNH 62150 & SDSNH 50599 \\
\hline P2L & & 4.11 & \\
\hline P2W & & 1.70 & \\
\hline P3L & & 4.90 & \\
\hline P3W & & 2.59 & \\
\hline P4L & 7.39 & 6.99 & \\
\hline P4W & 4.47 & 4.88 & \\
\hline M1L & 4.23 & & \\
\hline M1W & 7.70 & & \\
\hline M2L & 2.57 & & \\
\hline M2W & 4.93 & & \\
\hline P4-M2L & 12.86 & & \\
\hline p3L & & & 4.81 \\
\hline p3W & & & 2.02 \\
\hline p4L & & & 5.39 \\
\hline $\mathrm{p} 4 \mathrm{~W}$ & & & 2.46 \\
\hline m1L & & & $\sim 6.2$ \\
\hline $\mathrm{m} 1 \mathrm{~W}$ & & & 3.86 \\
\hline m1 trigonid length & & & 4.21 \\
\hline $\mathrm{m} 1$ trigonid height & & & 6.67 \\
\hline mandibular depth & & & 7.3 \\
\hline
\end{tabular}

labial margin of tooth from apex of paracone at least $70 \%$ greater than that from apex of metacone); Xinyuictis in less prominent cingulum of $\mathrm{P} 4$, absence of cusp on labial ridge of $\mathrm{M} 1$ at ectoflexus, and broader M1 posterior lingual cingulid; Paroodectes in smaller second molars relative to first molars $(\mathrm{M} 2 \mathrm{~L} / \mathrm{M} 1 \mathrm{~L}=0.61$ in holotype compared to $\mathrm{m} 2 \mathrm{~L} / \mathrm{m} 1 \mathrm{~L} \approx 0.9$ in a cast (UCMP 123612) of holotype of $P$. feisti); Quercygale in better-developed lingual cingulum of M1 and more labial position of apex of paracone relative to apex of metacone in M1; Tapocyon in less-pronounced labial elongation of M1 parastylar region, and larger second molars relative to first molars; 'Miacis' uintensis (whose upper dentition is poorly known) in substantially smaller size; Procynodictis in substantially smaller size (M1L x M1W approximately $37 \%$ smaller than in AMNH 2514 (P. vulpiceps) and 54\% smaller than in SDSNH 42813 ( $P$. progressus)) and better-developed anterior portion of M1 lingual cingulum that continues around protocone to posterior portion.

Further differs from: Dawsonicyon, Gracilocyon, Miocyon, Oodectes, Paramiacis, Palaearctonyx, Vassacyon, and Vulpavus in smaller second molars relative to first molars ((M2L x M2W)/(M1L x $\mathrm{M} 1 \mathrm{~W})=0.39$ in holotype); Uintacyon in less-pronounced posterolabial projection of M1 metastylar region (resulting in a shallower angle of the ectoflexus at approximately $140^{\circ}$ ) and clear separation of M1 postprotocrista from posterior lingual cingulum; Gracilocyon in less-pronounced posterolabial projection of $\mathrm{M} 1$ metastylar region and greater anteroposterior asymmetry of $\mathrm{M} 1$ lingual cingulum across protocone; 'Miacis' washakius in greater anteroposterior constriction of lingual portion of M1 and more labial (rather than anterolabial) direction of projection of M1 parastylar region; Ceruttia in presence of preparacrista on P4 and anteroposteriorly more asymmetrical lingual cingulum of M1.

Description. Unless otherwise noted, the following description of upper dentition pertains to the holotype. The referral of SDSNH 62150 to Walshius pacificus is based mainly on the presence of a preparacrista on the P4 and the anterior position of the P4 protocone. All dental dimensions are reported in Table 2.

The P2 of SDSNH 62150 (Figure 4.2) has a small bulge on the posterior slope of the main cusp that may represent an incipient posterior accessory 
cusp. The posterior cingulum forms a small, rather flat shelf. The P3 of SDSNH 62150 (Figure 4.2) bears a posterior accessory cusp positioned between a pair of small notches. A small cuspule on the posterior cingulum forms a ridge that bisects the cingular shelf in occlusal view. In the holotype, a relatively large infraorbital foramen is present on the maxilla above the position of P3. The P4 is rather slender in occlusal view (Figure 4.1). The small protocone has approximately the same height as the protocone of M1. In both the holotype and SDSNH 62150, a well-defined parastyle is lacking other than a very small bulge of the anterior labial cingulum at the base of preparacrista. Both the labial and lingual cingula are well-delineated except at the base of the protocone. The trenchant postparacrista runs nearly vertically along the posterior surface of paracone, followed by a deep carnassial notch that separates the paracone from the metastylar blade. The dorsal excavation of maxilla between the P4 and M1 is notably deep, presumably to accommodate a tall $\mathrm{m} 1$ trigonid (see below and Figure 4.3).

The M1 (Figure 4.1) is marked by labial elongation of the parastylar region, which protrudes considerably more labially than the posterolabial extremity of the P4. The segment of preparacrista labial to the base of paracone is oriented nearly perpendicular to the long axis of tooth row. The sharp ridge formed by this segment is relatively long but descends to the stylar shelf before reaching the anterolabial extremity of the parastylar region. A pair of small notches separates the paracone from the labial segment of preparacrista and paraconule. Both the preparacrista and centrocrista are trenchant. The paracone is roughly twice as long and tall as the metacone. The stylar shelf is broad and mostly flat. A slightly crenulated ridge is present along the labial margin of the stylar shelf where it meets the labial cingulum. The small paraconule is lower in height than the protocone and is somewhat angular. The vestigial metaconule is still lower in height but forms a triangular shelf. The protocone has approximately the same height as the metacone. In occlusal view, the apex of protocone overlaps with the anterolingual margin of the tooth. The anterolingual base of the protocone is almost confluent with the lingual cingulum, dividing the lingual cingulum into the anterior and the posterior portions. The anterior lingual cingulum is a narrow strip, whereas the posterior lingual cingulum is a relatively broad shelf that extends posterolingually, making the lingual portion of the tooth noticeably asymmetrical in occlusal view. Unlike in some caniform carnivorans, the posterior lingual cingulum does not form a raised ridge, and hypocone is absent.

The M2 (Figure 4.1) is anteroposteriorly compressed. The parastylar region is labially extended such that its labial border is in line with the posterolabial border of M1. The labial segment of preparacrista is not as well-developed as in the M1 and runs anterolabially until it reaches the margin of the tooth. The stylar shelf is broad and flat, but the ridge that marks its labial border is less developed than in the M1. A small notch is present between the labial segment of preparacrista and paracone. As in the $M 1$, the preparacrista and centrocrista form clear ridges, and the paracone is roughly twice as long and tall as the metacone. The metacone protrudes slightly posteriorly beyond the trigon basin. The paraconule and metaconule are essentially absent, and the trigon basin is shallow. The protocone is located more posteriorly than in the $\mathrm{M} 1$; it is entirely confluent with the broad and bulbous lingual cingulum, reaching approximately the same height as the metacone. The small extension of the maxilla posterior to the M2 does not bear an alveolus for a succeeding tooth, suggesting the absence of M3.

Remarks. The upper dentition of Walshius pacificus is marked by the presence of posterior accessory cusp on P3, anterolingual placement of M1 protocone, labial elongation of parastylar region of M1 (extending beyond the labial extremity of P4), and narrow M2. In these respects, the new taxon most closely resembles Procynodictis (known from the Uintan NALMA). However, the substantially smaller size and apparently more primitive morphology of M1 lingual cingulum make $W$. pacificus sufficiently distinct from Procynodictis to warrant the designation of a separate genus. Pronounced elongation of $\mathrm{M} 1$ parastylar region and reduction in the size of posterior molars also characterize Bridgerian carnivoraforms 'Miacis' hargeri, 'M.' sylvestris, and ' $M$.' washakius, but the current generic classifications of these taxa are questionable (for the most-recent cladistic hypotheses, see Tomiya, 2011; Spaulding and Flynn, 2012); consequently, assignment of the new taxon to the genus Miacis is best avoided. Although proper cladistic analysis must wait until additional material is discovered, the presence of posterior accessory cusp on P3 (also known in Tapocyon, 'Miacis' gracilis, and Lycophocyon) hints at the proximity of $W$. pacificus to crown-group carnivorans (cf. Wang and Tedford, 1994; Wesley-Hunt and Flynn, 2005). 


\section{cf. Walshius pacificus}

Figure 4.3-4.5

Referred Specimen. SDSNH locality 3788 , Stonecrest Square Site 8, Friars Formation, San Diego, San Diego County, California, USA: SDSNH 50599, right dentary fragment with p3-m1.

Description. The anterior cingulids of $\mathrm{p} 3$ and $\mathrm{p} 4$ form pointed cuspulids that are aligned with the main cuspids (Figure 4.3-5). The main cuspids of p3 and p4 bear ridges on their anterior and posterior slopes. A very minor bulge is present on the posterior slope of the main cuspid of $p 3$. The $p 4$ has a better-defined posterior accessory cuspid posterior to a very small notch. The posterior cingulid is anteroposteriorly traversed by a very small (p3) to small (p4) ridge. On the p4, posterior accessory cuspid and the ridge on the posterior cingulid are positioned slightly more labially than the main cuspid, giving rise to a small lingual basin on the posterior cingulid.

The morphology of $\mathrm{m} 1$ is marked by the tall protoconid (Figure 4.3-4, Table 2). The paraconid and metaconid are each rather compressed, resulting in a prefossid that is dorsolingually wide open (Figure 4.5). The trigonid is relatively open, and the metaconid projects slightly more lingually than the lingual margin of talonid. The short talonid likely had less than half the length of trigonid. The morphology of the talonid basin and the surrounding cuspids is obscured by breakage of the posterolingual portion, which has apparently been displaced anterodorsally; the notably steep anterior descent of the labial wall of talonid (Figure 4.3) may be an artifact of this breakage.

Remarks. None of the currently known specimens of Walshius pacificus preserves upper and lower teeth in association. The referral of SDSNH 50599 to $W$. pacificus is tentatively justified based on: 1) the tall trigonid and anteroposteriorly short talonid (although apparently broken) of $\mathrm{m} 1$, which are consistent with the anterior placement of the M1 protocone and the deep excavation of maxilla between the P4 and M1 in the holotype; 2) the morphological concordance between the posterior accessory cuspid of p4 and the posterior accessory cusp of P3 (Figure 4.2-4); 3) the slender protoconid of m1 (Figure 4.3-4), which is consistent with the labially constricted space between P4 and M1 in the holotype (Figure 4.1). The combination of these traits is lacking in other similar-sized carnivoraforms from the middle Eocene of southern California.

The well-developed cingular cuspulids and forms of posterior accessory cuspids make the p3 and p4 appear particularly similar to those of Pro- cynodictis vulpiceps, lending additional support to the phylogenetic proximity of Walshius to Procynodictis. The $\mathrm{m} 1$ of Procynodictis, with its more open trigonid and reduced metaconid, is apparently more derived toward the condition in early canids; however, the tall protoconid is common to the two genera. Taken together, the upper dentition of holotype and the lower dentition of SDSNH 50599 present a plausible ancestral morphotype for the genus Procynodictis, assuming that distinguishing characteristics of Procynodictis such as the more open $\mathrm{m} 1$ trigonid and the more blade-like posterior accessory cuspid of p4 represent derived conditions in the direction of basal canids.

Genus PROCYNODICTIS Wortman and Matthew, 1899

Figure 5.1, 5.3-5.4, 5.7-5.18

Type Species. Procynodictis vulpiceps Wortman and Matthew, 1899.

Included Species. Procynodictis progressus Stock, 1935.

Emended Diagnosis. Differs from viverravids in reduced parastyle and protocone of P4, short talonid of $\mathrm{m} 2$, and presence of $\mathrm{m} 3$. Differs from other basal carnivoraforms in: upper molars anteroposteriorly compressed; M1 protocone positioned close to anterolingual margin of tooth such that anterior border of tooth is oriented nearly perpendicular to long axis of tooth row; lingual cingulum of $\mathrm{M} 1$ vestigial anterior to protocone but moderately developed posterior to protocone; labially-elongate parastylar region of $\mathrm{M} 1$ (but proportionately less elongate than in Tapocyon); posterolabial margin of M1 (labial to metacone) not extending beyond deepest point of ectoflexus; $p 4$ with well-developed and trenchant posterior accessory cuspid followed by a ridge on posterior cingulid; lingual deflection of anterior cingulid of $\mathrm{p} 4$; transversely-compressed trigonid of $\mathrm{m} 1$, wherein the angle between lines connecting apices of paraconid, protoconid, and metaconid is roughly $70^{\circ}$; transversely compressed talonid of $\mathrm{m} 1$; metaconid of $\mathrm{m} 1$ more slender than paraconid; $m 2$ with roughly half the length of $m 1$. In particular, differs from 'Miacis' gracilis in more anterior position of M1 protocone and consequently more asymmetrical lingual cingulum, less pronounced posterior slanting of labial segment of M1 preparacrista, greater anterolabial extension of M1 parastylar region, smaller anterior accessory cuspulid on p3, and steeper anterior and posterior slopes of the main cusp of $\mathrm{p} 4$.

Distribution. Portions of the Uinta Formation, Utah, Wagon Bed Formation, Wyoming, Sespe Formation, California, Mission Valley Formation, 

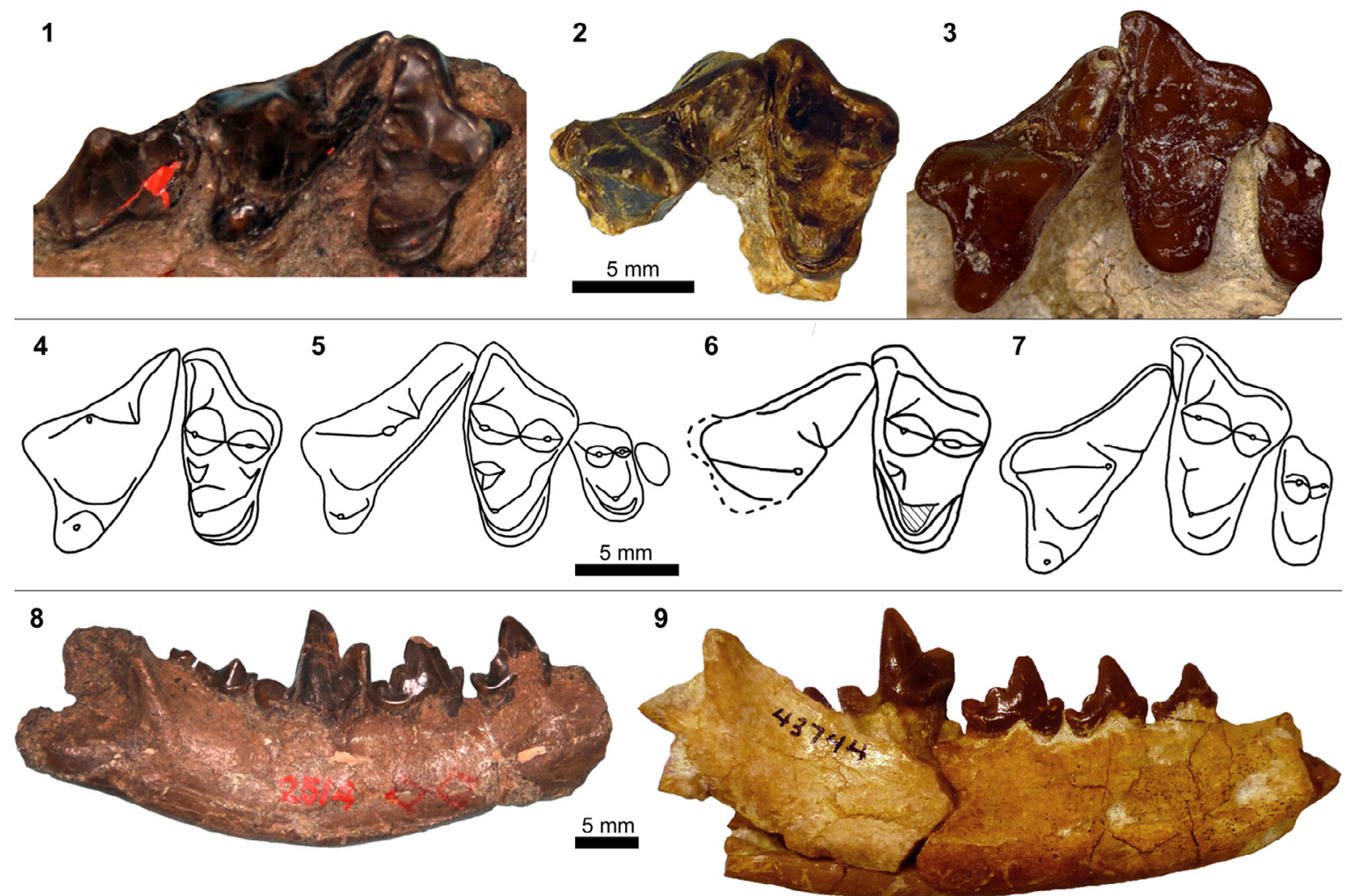

10

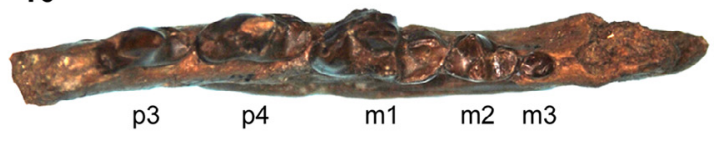

11

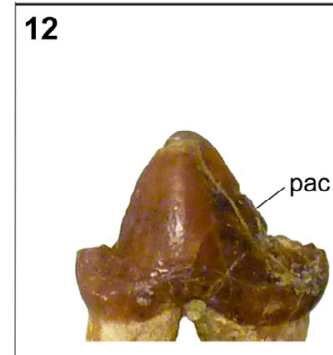

13

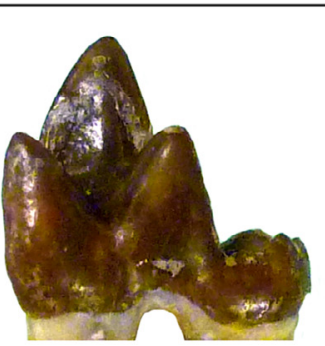

14

15
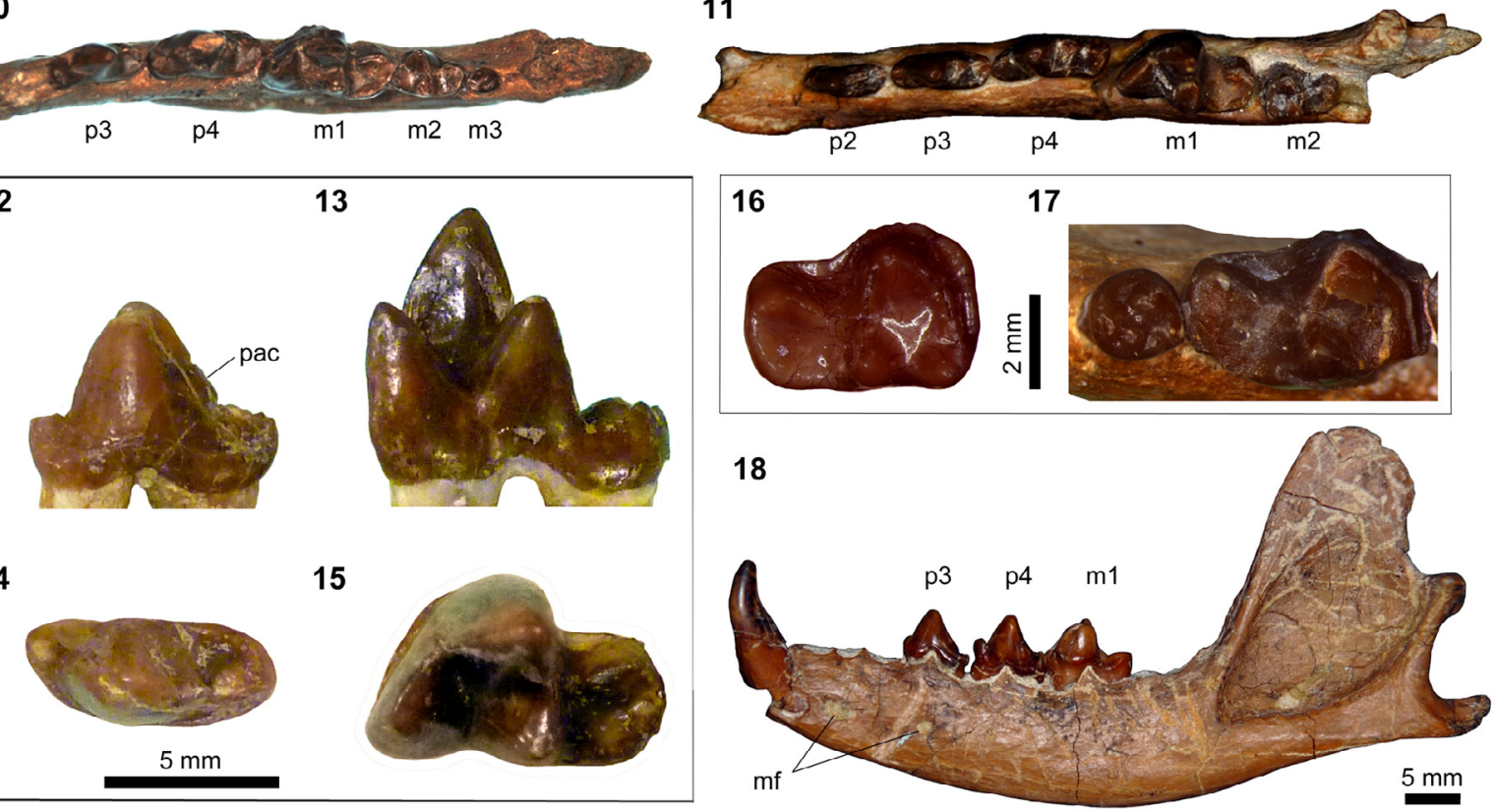

FIGURE 5. Dentition of Procynodictis and 'Miacis' gracilis. P. vulpiceps (AMNH 2514, Uinta Formation): left P3-M1 (1, 4); right dentary in labial (8) and occlusal (10) views. P. progressus (Santiago Formation): SDSNH 42813, left P4-M2 $(3,7)$; SDSNH 43744, right dentary in labial (9) and occlusal (11) views and left m2-m3 in occlusal view (17); SDSNH 43656, left $\mathrm{m} 2$ in occlusal view (16); SDSNH 42810, left dentary in labial view (18). Cf. 'M.' gracilis: LACM 40450, right P4-M1 from the Sespe Formation (2, 6; inverted). 'M.' gracilis: AMNH 104960 (cast of CM 12063) from the Uinta Formation (5). Cf. Procynodictis sp.: SDSNH 47389, left p4 in labial (12) and occlusal (14) views; SDSNH 55888, right m1 in lingual (13) and occlusal (15) views. Abbreviations: mf, mental foramina; pac, posterior accessory cuspid. 
TABLE 3. Dental dimensions of the holotype of Procynodictis vulpiceps. Measurements in millimeters. Where applicable, the arithmetic mean of measurements for the right and left teeth is reported.

\begin{tabular}{ll}
\hline & AMNH 2514 \\
\hline P1L & 3.58 \\
P1W & 2.15 \\
P2L & 5.97 \\
P2W & 2.53 \\
P3L & 7.28 \\
P3W & 3.71 \\
P4L & 9.57 \\
P4W & 6.58 \\
M1L & 5.36 \\
M1W & 9.60 \\
p3L & 6.65 \\
p3W & 2.75 \\
p4L & 7.96 \\
p4W & 3.33 \\
m1L & 9.29 \\
m1W & 4.45 \\
m2L & 4.87 \\
m2W & 3.24 \\
m3L & 2.15 \\
m3W & 1.79 \\
\hline & 10.37 \\
\hline & \\
\hline & \\
mandibular depth & \\
\hline & \\
\hline
\end{tabular}

California, and Laredo Formation, Texas, USA, corresponding to the biochrons Ui2 and Ui3 of Uintan NALMA (cf. Dawson, 1980; Westgate, 1990; Walsh et al., 1996; Prothero, 2001; Robinson et al., 2004; Gunnell et al., 2009; Kelly et al., 2012), and possibly portions of the Friars Formation, California, corresponding to the biochron Ui1b (cf. Walsh et al., 1996; Robinson et al., 2004; Gunnell et al., 2009).

Remarks. Measurements of the holotype AMNH 2514 of Procynodictis vulpiceps are provided in Table 3. The diagnostic characters listed above are limited to those that are known in both $P$. vulpiceps and $P$. progressus. None of the known specimens of $P$. vulpiceps preserves the M2. Presence or absence of M3 in the genus is unknown. The fusion of scaphoid and lunar is known in $P$. vulpiceps (Wortman and Matthew, 1899) but not in $P$. progressus.
As discussed below, some authors have considered 'Miacis' gracilis to be synonymous with $P$. vulpiceps (e.g., Wang and Tedford, 1996; Spaulding and Flynn, 2012). While 'M.' gracilis is here treated as a distinct taxon, its close affinity with Procynodictis is probable judging from marked similarities in dental morphology.

Procynodictis progressus (Stock, 1935)

Figure 5.3, 5.7, 5.9, 5.11, 5.16-5.18

$\mathrm{V}^{*} 1935$ Viverravus (Plesiomiacis) progressus Stock, p. 120, fig. 1.

1945 Plesiomiacis progressus (Stock); Simpson, p. 108.

1982 Procynodictis progressus (Stock); Flynn and Galiano, p. 57.

Holotype. LACM CIT 1776, right dentary with p2$\mathrm{m} 2$.

Holotype Locality. LACM locality CIT 207, Brea Canyon, Sespe Formation, middle member, Simi Valley, Ventura County, California, USA.

Paratype. LACM locality CIT 207, Brea Canyon, Sespe Formation, middle member, Simi Valley, Ventura County, California, USA: LACM CIT 1777, left maxillary fragment with $\mathrm{P} 4, \mathrm{M} 1$, and broken M2.

Referred Specimens. SDSNH locality 3276, Jeff's Discovery, Santiago Formation, member C, Oceanside, San Diego County, California, USA: SDSNH 43656, left m2.

SDSNH locality 3561, Jeff's Discovery, Santiago Formation, member C, Oceanside, San Diego County, California, USA: SDSNH 47642, right dentary with $\mathrm{p} 2-\mathrm{m} 2$.

SDSNH locality 3562, Jeff's Discovery, Santiago Formation, member $\mathrm{C}$, Oceanside, San Diego County, California, USA: SDSNH 42810, left dentary with c, p3-m1; SDSNH 42813, left maxillary fragment with P4-M2; SDSNH 47191, right P4.

SDSNH locality 3564, Jeff's Discovery, Santiago Formation, member C, Oceanside, San Diego County, California, USA: SDSNH 43744, associated right and left dentaries with right p2-m2 and left c, p2-m3; SDSNH 48100, left dentary fragment with p4-m2; SDSNH 52664, right p4.

SDSNH locality 3870, Scripps Ranch North Site 70, Mission Valley Formation, San Diego, San Diego County, California, USA: SDSNH 54413, left dentary fragment with p2-m2; SDSNH 54414, right dentary fragment with m1-2; SDSNH 54416, left maxillary fragment with $\mathrm{P} 4-\mathrm{M} 1$.

Distribution. The middle member of Sespe Formation, the Mission Valley formation, and member C of the Santiago Formation, California, USA, corresponding to the biochron Ui3 of Uintan NALMA 
TABLE 4. Dental dimensions of Procynodictis progressus. Measurements in millimeters. Where applicable, the arithmetic mean of measurements for the right and left teeth is reported. ${ }^{1}$ Measurements not reported because of heavy dental wear or breakage. ${ }^{2}$ Estimated because of ventral breakage.

\begin{tabular}{|c|c|c|c|c|c|c|c|c|c|}
\hline & $\begin{array}{c}\text { LACM CIT } \\
1776\end{array}$ & $\begin{array}{l}\text { SDSNH } \\
42813\end{array}$ & $\begin{array}{l}\text { SDSNH } \\
47191\end{array}$ & $\begin{array}{c}\text { SDSNH } \\
54416\end{array}$ & $\begin{array}{c}\text { SDSNH } \\
42810\end{array}$ & $\begin{array}{l}\text { SDSNH } \\
43744\end{array}$ & $\begin{array}{l}\text { SDSNH } \\
47642\end{array}$ & $\begin{array}{l}\text { SDSNH } \\
48100\end{array}$ & $\begin{array}{c}\text { SDSNH } \\
54413\end{array}$ \\
\hline P4L & & 10.13 & 8.60 & 8.79 & & & & & \\
\hline P4W & & 6.08 & 5.69 & 5.64 & & & & & \\
\hline M1L & & 6.38 & & 6.05 & & & & & \\
\hline M1W & & 10.70 & & 10.00 & & & & & \\
\hline M2L & & 3.01 & & & & & & & \\
\hline $\mathrm{M} 2 \mathrm{~W}$ & & 6.33 & & & & & & & \\
\hline$c L$ & & & & & 4.45 & 4.50 & & & \\
\hline $\mathrm{cW}$ & & & & & 3.11 & 3.42 & & & \\
\hline $\mathrm{p} 1 \mathrm{~L}$ & 2.83 & & & & & & & & \\
\hline $\mathrm{p} 1 \mathrm{~W}$ & 1.48 & & & & & & & & \\
\hline p2L & 5.15 & & & & & 5.43 & 4.56 & & 5.20 \\
\hline $\mathrm{p} 2 \mathrm{~W}$ & 2.26 & & & & & 2.18 & 2.27 & & 2.27 \\
\hline p3L & 6.54 & & & & 5.84 & 6.73 & 6.07 & & \\
\hline p3W & 2.89 & & & & 2.64 & 2.61 & 2.63 & & \\
\hline $\mathrm{p} 4 \mathrm{~L}$ & 7.12 & & & & 7.08 & 8.07 & 6.74 & & 6.71 \\
\hline $\mathrm{p} 4 \mathrm{~W}$ & 3.27 & & & & 2.92 & 3.14 & 2.98 & & 2.78 \\
\hline $\mathrm{m} 1 \mathrm{~L}$ & 9.04 & & & & $\sim 8.0$ & 9.30 & 8.88 & 8.50 & 8.37 \\
\hline $\mathrm{m} 1 \mathrm{~W}$ & 4.67 & & & & 4.80 & 5.28 & 4.67 & $\sim 4.6$ & 4.97 \\
\hline $\begin{array}{l}\mathrm{m} 1 \text { protoconid } \\
\text { height }\end{array}$ & na ${ }^{1}$ & & & & & 8.35 & & & \\
\hline $\begin{array}{l}\mathrm{m} 1 \text { metaconid } \\
\text { height }\end{array}$ & $\mathrm{na}^{1}$ & & & & & 5.78 & & & \\
\hline $\mathrm{m} 2 \mathrm{~L}$ & $\sim 5.1$ & & & & & 5.23 & na1 & 4.71 & 4.68 \\
\hline $\mathrm{m} 2 \mathrm{~W}$ & 3.24 & & & & & 3.51 & na1 & 3.23 & 3.37 \\
\hline $\mathrm{m} 3 \mathrm{~L}$ & & & & & & 1.96 & & & \\
\hline $\mathrm{m} 3 \mathrm{~W}$ & & & & & & 2.01 & & & \\
\hline $\begin{array}{l}\text { mandibular } \\
\text { depth }\end{array}$ & $\sim 11.7^{2}$ & & & & 12.62 & 13.73 & 12.30 & 11.32 & 11.19 \\
\hline
\end{tabular}

(cf. Prothero et al., 1996; Walsh, 1996; Prothero, 2001; Robinson et al., 2004; Kelly et al., 2012).

Description. Two well-preserved specimens from San Diego County are described here to supplement the original description of heavily worn type specimens from the Sespe Formation by Stock (1935). Measurements are given in Table 4.

Of the upper dentition, only P4 to M2 are currently known. The P4 of SDSNH 42813 (Figure 5.3, 5.7) lacks a clearly-recognizable parastyle, although a small bulge is present on the paratype
LACM CIT 1777. A thin cingulum wraps the base of labial surface but is absent from the posterolingual wall of P4. As in the paratype LACM CIT 1777, the anterolabial base of paracone projects anteriorly rather than anterolabially, giving the tooth an occlusal outline that is distinct from the P4 of Procynodictis vulpiceps (compare Figure 5.3, 5.7, with 5.1, 5.4).

On the M1, the prominent labial segment of preparacrista exhibits a slight posterior tilt as it approaches the labial margin of the tooth, and its 
merger with the labial cingulum creates an Lshaped ridge leading to the anterior extremity of the parastylar region. As observed by Stock (1935) for the paratype LACM CIT 1777, the paracone of M1 is considerably larger than the metacone, having roughly twice the height of the latter cusp. The paraconule is poorly developed, and the metaconule is either absent or vestigial and worn down in SDSNH 42813. The lingual cingulum is largely confluent with the base of protocone, and forms a very thin shelf posterior to this cusp.

The reduced $\mathrm{M} 2$ is highly compressed in the anteroposterior direction. The parastylar region is labially extended, although the labial border of the tooth is nearly strait. The relatively well-developed paracone dominates the diminutive metacone located close to the posterior edge of the tooth. The low protocone has the appearance of having been incorporated into the bulbous lingual cingulum. In the paratype LACM CIT 1777, the maxilla seems to terminate naturally behind M2 without any trace of alveolus for $M 3$, supporting the absence of this tooth as was claimed by Stock (1935) in his original description.

The dentary has a moderately deep horizontal ramus (Figure 5.9, 5.18). The ascending ramus rises steeply behind the $\mathrm{m} 3$ (at an angle of roughly $70^{\circ}$ in SDSNH 42810), leading to the anteroposteriorly rather broad coronoid process. The masseteric fossa is quite deep, and the bone becomes very thin at and around the deepest part of this fossa. The posteriorly directed angular process extends slightly beyond the posterior margin of mandibular condyle. The anterior and posterior mental foramina are located beneath the junction between $\mathrm{p} 1$ and $\mathrm{p} 2$ and under the $\mathrm{p} 3$, respectively. The moderately sized lower canines of SDSNH 42810 and SDSNH 43744 are labiolingually somewhat compressed and each bear a slight posterior bulge at the base of crown.

As in Procynodictis vulpiceps, a small diastema is present between the p2 and p3 (Figure 5.9, 5.11). The second through fourth premolars have rather elongate posterior cingulids such that the apices of their main cusps are located anterior to the midpoints along the lengths of these teeth. The anterior cingulid is small in the p2 and p3 but is well-developed in the $\mathrm{p} 4$. The apices of main cusps of p2, p3, and p4 are essentially aligned at the same horizontal level. On all of these premolars, the series of ridges running along their lengths are accentuated.

The p2 has a simple form with no accessory cuspid, and is longer than tall. The main cuspid rises steeply on its anterior side, but its posterior slope descends more gently toward the posterior cingulid. In occlusal view (Figure 5.11), the anterior cingulid tapers anterolingually, while the posterior cingulid tapers posterolabially.

The p3 is similar in form to the smaller p2 but bears a relatively taller main cuspid and a betterdeveloped anterior cingulid. A small posterior accessory cuspid is present as a raised ridge at the base of the posterior slope of main cuspid, connecting to the anteroposterior ridge on the posterior cingulid; in occlusal view, these ridges are located close to the labial margin of the tooth, leaving the lingual portion of the posterior cingulid to form a relatively flat shelf (Figure 5.11). Although the anterior portion of the tooth is slightly asymmetrical in occlusal view (the lingual margin tapers more abruptly than the labial one), it does not show the pronounced lingual deflection as in the $\mathrm{p} 4$.

The p4 is characterized by the trenchant ridges formed by the anterior and posterior cingulids as well as the well-developed posterior accessory cuspid. The posterior accessory cuspid is located at a relatively low height and abruptly interrupts the steeply-descending posterior slope of main cuspid, contributing to the distinctly steplike profile of the posterior portion of tooth (Figure 5.9). In SDSNH 43744, the anterior portion of the tooth is strongly deflected in the lingual direction (Figure 5.11), more than in the holotype LACM CIT 1776. As in the p3, the posterior accessory cuspid and the ridge on posterior cingulid are positioned labially, and the latter is flanked by a relatively flat shelf on its lingual side.

The $\mathrm{m} 1$ is marked by the protoconid that is tall compared to paraconid and rises vertically (Figure 5.9). The relatively anterior placement of paraconid and the somewhat lingual position of protoconid create a transversely-narrow but anteroposteriorlyopen trigonid (Figure 5.11). The metaconid is more slender than the paraconid, but the two cuspids have approximately the same height. Both the talonid and talonid basin are narrow. The latter is labially bordered by a trenchant cristid obliqua. The cuspids of talonid are apparently incorporated to the ridge that surrounds the basin, and are not individually recognizable.

Corresponding to the narrow talonid of $\mathrm{m} 1$, the $\mathrm{m} 2$ is small in size (Figure 5.11). The tooth bears a well-defined cingulid anterior to the trigonid (Figure 5.16). The trigonid cuspids have essentially the same height as the talonid of $\mathrm{m} 1$. Whereas the trigonid of $\mathrm{m} 2$ in occlusal view is roughly equilateral in Procynodictis vulpiceps (Figure 5.10), it is more 
closed in SDSNH 43744 such that the angle between the line connecting the paraconid to protoconid and the line connecting the protoconid to metaconid is approximately $35^{\circ}$. The shape of narrow talonid essentially mirrors that of $\mathrm{m} 1$ talonid. The curvature of the posterolingual corner of talonid is somewhat variable, turning more abruptly in SDSNH 43656 (Figure 5.16) than in SDSNH 48100. The shallow talonid basin is demarcated by a low ridge. The anterior descent of cristid obliqua (clearly seen in SDSNH 43656) is obliterated in moderately worn teeth such as that of SDSNH 43744 (Figure 5.17) and SDSNH 48100.

The m3 of SDSNH 43744 has an oval outline in occlusal view and approximately the same length as the talonid of $\mathrm{m} 2$ (Figure 5.17). A vestige of trigonid is marked by a somewhat bulbous and very low protoconid. The anterior portion of reduced trigonid shows noticeable wear. Two diminutive cuspulids are located lingual and posterolingual to the protoconid; the anterior one of these cuspulids may represent a reduced metaconid. There is no talonid or basin posterior to the reduced trigonid. Instead, the posterior end of crown is slightly elevated to reach nearly the same level as the protoconid.

Remarks. Although Stock (1935) noted its similarities with "miacines" (equivalent to basal carnivoraforms), he assigned the new taxon from Simi Valley to a newly erected subgenus Plesiomiacis within the genus Viverravus based on the apparent absence of third molars (N. B. the presence of $\mathrm{m} 3$ is now known), well-developed posterior accessory cuspids of $\mathrm{p} 3$ and $\mathrm{p} 4, \mathrm{~m} 1$ with tall trigonid and reduced talonid, and small $\mathrm{m} 2$. Subsequently, Simpson (1945) recognized Plesiomiacis as a distinct genus while he retained its placement in the Viverravidae (then the Viverravinae). Additional observations led Flynn and Galiano (1982) to reclassify Plesiomiacis progressus as a species of Procynodictis. The fossil material from San Diego County described here corroborates the taxonomic opinion of Flynn and Galiano (1982). As noted by these authors, the dentition of $P$. progressus shows unquestionable affinity to $P$. vulpiceps, although the morphological differences are sufficient enough to warrant their recognition as separate species. These differential traits include: the anterior projection of the anterolabial base of P4 paracone in $P$. progressus; better-defined, if still narrow, shelf of the posterior lingual cingulum ("hypocone" of Flynn and Galiano, 1982, p. 57) in P. vulpiceps; and more open trigonid of $\mathrm{m} 2$ in $P$. vulpiceps. The two species of Procynodictis are comparable in size
(Tables 3, 4). The lower dentition of Procynodictis is notably similar to those of 'Miacis' gracilis from the Uinta Formation (see below), Cynodictis compressidens from the late Eocene of France (cf. Teilhard de Chardin, 1914-1915) and 'Miacis' lushiensis from the middle Eocene of China (cf. Chow, 1975; but note the less labiolingually compressed $\mathrm{m} 1$ than in Procynodictis).

\section{cf. Procynodictis sp. \\ Figure 5.12-5.15}

Referred Specimens. SDSNH locality 3617 , Scripps Ranch North Site 17, Friars Formation, conglomerate tongue, San Diego, San Diego County, California, USA: SDSNH 54896, right dentary fragment with alveoli for $\mathrm{m} 1$, broken root of $\mathrm{m} 2$, and alveolus for m3; SDSNH 58908, left m1 fragment.

SDSNH locality 3621, Scripps Ranch North Site 20-B, Friars Formation, conglomerate tongue, San Diego, San Diego County, California, USA: SDSNH 55888, right $\mathrm{m} 1$.

SDSNH locality 3681, Route 56 East Site 1, Friars Formation, upper tongue, San Diego, San Diego County, California, USA: SDSNH 46581, right m2; SDSNH 47389, left p4.

Remarks. Five specimens from the Friars Formation represent isolated lower teeth and a dentary fragment that show close resemblances with corresponding elements of the genus Procynodictis. Notable similarities include: (1) p4 characterized by a well-developed, lingually deflected anterior cingulid, steeply rising anterior slope of the main cuspid, and a trenchant posterior accessory cuspid (Figure 5.12, 5.14); (2) m1 with a narrow talonid, a shallow talonid basin, and primarily anteroposterior orientation of both the cristid obliqua and the segment of paralophid between carnassial notch and apex of protocone (Figure 5.13, 5.15); and (3) m2 that is essentially indistinguishable from that of $P$. progressus. However, the trigonid of $\mathrm{m} 1$ (SDSNH 55888 ) is noticeably more closed than those of $P$. vulpiceps and $P$. progressus, and the metaconid of $\mathrm{m} 1$ is as robust as the paraconid. In addition, the posterior accessory cuspid of p4 (SDSNH 46581) is positioned slightly more dorsally and is somewhat less prominent than those of $P$. vulpiceps and $P$. progressus. These specimens may therefore belong to a morphologically distinct lineage segment within the genus Procynodictis. Further taxonomic assessment will require additional material, especially of the upper dentition. Measurements of SDSNH 55888: $\mathrm{m} 1 \mathrm{~L}=8.61 \mathrm{~mm} ; \mathrm{m} 1 \mathrm{~W}=5.30 \mathrm{~mm}$; $\mathrm{m} 1$ trigonid length $=5.39 \mathrm{~mm}$. 


\section{cf. 'Miacis' gracilis (Clark, 1939)}

Figure 5.2, 5.5-5.6

V*1939 Miacis gracilis Clark, p. 349, fig. 1-2, pl. 3437.

p 1996 Procynodictis vulpiceps (Wortman and Matthew); Wang and Tedford, p. 448.

2010 'Miacis' gracilis (Clark); Friscia and Rasmussen, p. 58

Referred Specimen from Southern California. LACM locality CIT 180, Tapo Ranch, Sespe Formation, Simi Valley, Ventura County, California, USA: LACM 40450, right maxillary fragment with $\mathrm{P} 4$ and $\mathrm{M} 1$.

Tentatively Referred Specimen from Southern California. LACM locality CIT 180, Tapo Ranch, Sespe Formation, Simi Valley, Ventura County, California, USA: LACM 40451, left M1 fragment; LACM 40492, right M1 fragment; LACM 40495, left $\mathrm{m} 1$ trigonid.

Distribution. Portions of the Uinta Formation, Utah, and middle member of the Sespe Formation, California, USA, corresponding to the biochrons Ui2 and Ui3 of Uintan NALMA (Gunnell et al., 2009; Kelly et al., 2012).

Description. The referral of above-listed specimens other than LACM 40450 is tentative and is based on the absence of morphological evidence to the contrary as well as their occurrences at the same locality as LACM 40450. Although the dentition of Procynodictis progressus (particularly its lower dentition) is similar to that of 'Miacis' gracilis, no unambiguous specimen of the former taxon is known from the locality CIT 180.

LACM 40450 is intermediate in size between the smaller 'Miacis' hookwayi, known from the same locality, and Procynodictis progressus. The protocone of P4 is broken off in the specimen. The parastyle of P4 is either absent or vestigial (the pertinent portion of the tooth is slightly damaged). The base of P4 is surrounded by a well-defined cingulum. The preparacrista is a weakly developed ridge, whereas the postparacrista and metastylar blade are trenchant.

The parastylar region of M1 is moderately elongate such that the paracone is roughly equidistant from the protocone and the labial extremity of the tooth (Figure 5.2, 5.6). The labial segment of preparacrista slants in a slightly posterior direction as it approaches the labial border of tooth. The stylar shelf is rather wide and flat and is bordered by a well-delineated ridge of the labial cingulum. The paracone is approximately twice as tall as the metacone. The paraconule is minute, and the metaconule cannot be recognized on the speci- men. Although the apex of protocone is broken, it appears to have been positioned somewhat anterolingually. A thin but continuous lingual cingulum surrounds the base of protocone; it is somewhat thicker posterior to the protocone, but does not show the degree of anteroposterior asymmetry seen in Procynodictis and Walshius. Measurements: $\mathrm{P} 4 \mathrm{~L}=9.52 \mathrm{~mm} ; \mathrm{M} 1 \mathrm{~L}=5.71 \mathrm{~mm} ; \mathrm{M} 1 \mathrm{~W}=$ $9.90 \mathrm{~mm}$.

Remarks. In his original description of type and referred specimens, Clark (1939) differentiated Miacis gracilis from Procynodictis vulpiceps based on better-developed labial cingula of upper teeth, narrow lingual cingulum of M1 around the protocone, and presence of M3. Later, Wang and Tedford (1996) synonymized ' $M$.' gracilis with $P$. vulpiceps, and their classification was accepted in recent studies (e.g., Spaulding and Flynn, 2012). Since the publication of Clark's paper, no additional material of ' $M$.' gracilis has been described in the literature. Here, based on the newly identified specimen from southern California, I concur with Clark (1939), Dawson (1980), and Friscia and Rasmussen (2010) in recognizing the two taxa as distinct. Specifically, LACM 40450 and CM 12063 (both referred to ' $M$.' gracilis) are consistently distinguishable from the holotype AMNH 2514 of $P$. vulpiceps in: 1) relatively posterior position of $\mathrm{M} 1$ protocone; 2) more anteroposteriorly symmetrical lingual cingulum of M1 (as noted by Clark, 1939); 3 ) greater posterior slanting of the labial segment of M1 preparacrista; and 4) less pronounced anterolabial extension of the M1 parastylar region. In addition, the lower dentition of CM 11900 (holotype of ' $M$.' gracilis) differs from those of AMNH 2514 (P. vulpiceps; Figure 5.8) and SDSNH 43744 $(P$. progressus; Figure 5.9) in better-developed anterior accessory cuspulid of p3 and less steep anterior and posterior slopes of the main cusp of p4. Finally, the upper dentition of ' $M$.' gracilis is readily distinguished from that of $P$. progressus (Figure $5.3,5.7$ ) by the less anteroposteriorly compressed molars.

Despite these differences, the overall dental morphology of ' $M$.' gracilis bears strong resemblance to that of $P$. vulpiceps. As such, their phylogenetic proximity is plausible, although proper taxonomic re-assessment is at present hampered by the paucity of well-preserved specimens. For instance, unlike in $P$. vulpiceps (see Wortman and Matthew, 1899, figure 8), carpal elements of 'Miacis' gracilis are unknown (Clark, 1939).

\section{cf. 'Miacis' hookwayi (Stock, 1934)}

Figure 6 
PALAEO-ELECTRONICA.ORG

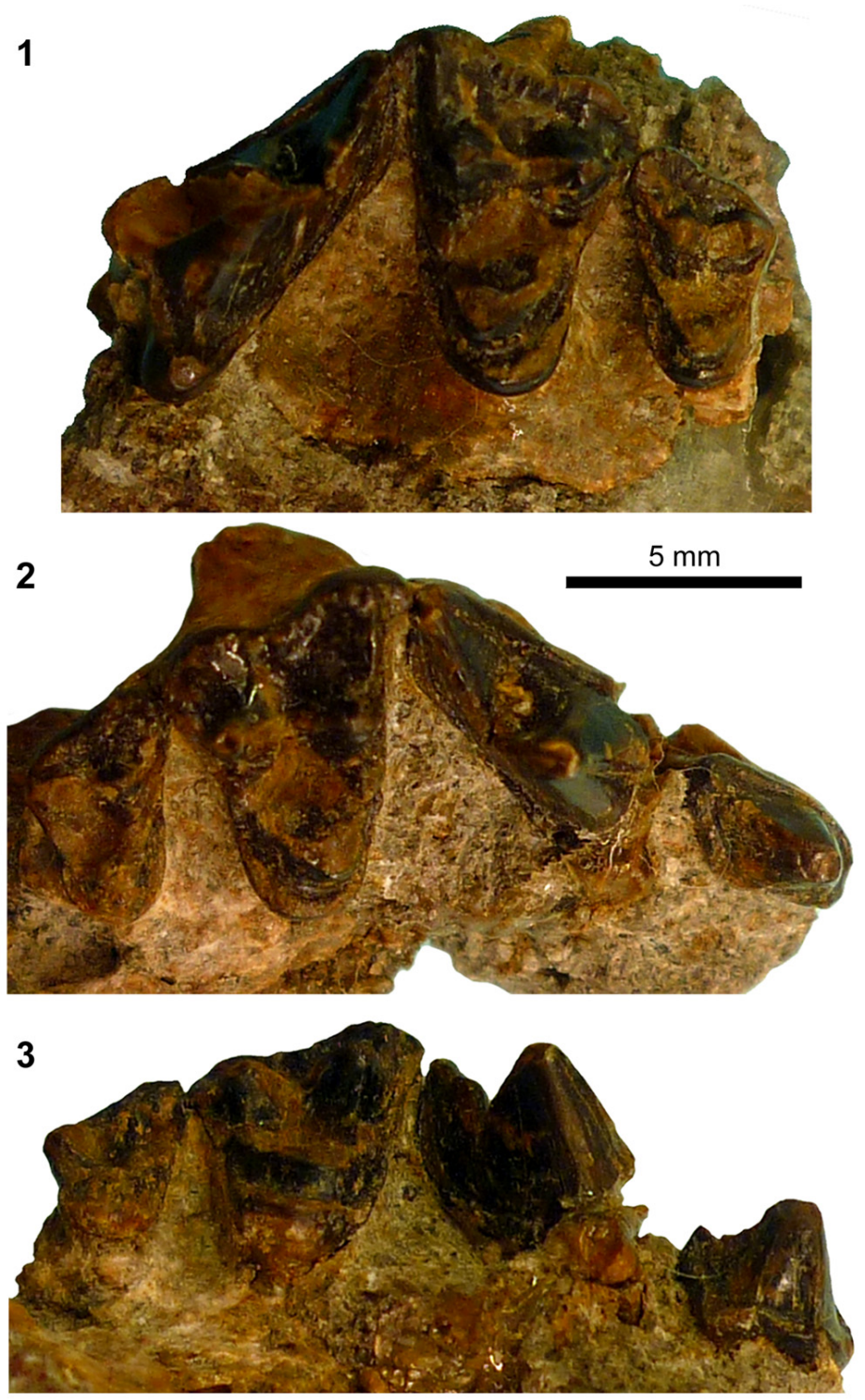

4

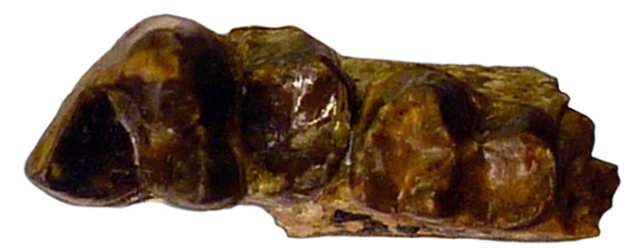

5

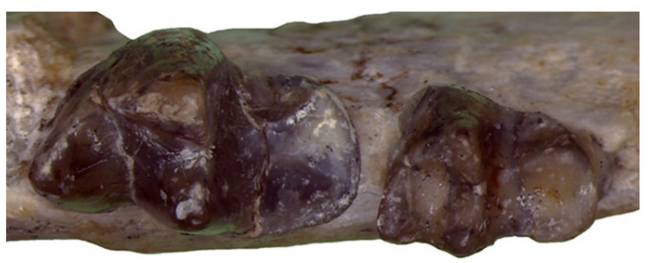

FIGURE 6. Dentition of specimens referred to 'Miacis' hookwayi. LACM 40463 (cf. 'Miacis' hookwayi), left maxillary fragment with P4-M2 (1) and right maxillary fragment with P3-M2 in occlusal (2) and lingual (3) views; LACM CIT 1656 (holotype), left dentary fragment with $\mathrm{m} 1-\mathrm{m} 2$ in occlusal view (4, inverted); SDSNH 84969, right $\mathrm{m} 1-\mathrm{m} 2$ in occlusal view (5). 
V*1934 Miacis? hookwayi Stock, p. 427, fig. 6, 6a. Referred Specimens. LACM locality CIT 180, Tapo Canyon, Sespe Formation, Simi Valley, Ventura County, California, USA: LACM 40463, right maxillary fragment with P3-M2 and left maxillary fragment with $\mathrm{P} 4-\mathrm{M} 2$.

SDSNH locality 4715, State Route 125 Grossmont (Unit II, Lower Green), Mission Valley Formation, El Cajon, San Diego County, California, USA: SDSNH 84969, right dentary fragment with $\mathrm{p} 2, \mathrm{~m} 1$, and $\mathrm{m} 2$.

Distribution. Portions of middle member of the Sespe Formation and the Mission Valley Formation, California, USA, probably corresponding to the biochron Ui3 of Uintan NALMA (cf. Prothero et al., 1996; Walsh, 1996; Prothero, 2001; Robinson et al., 2004; Kelly et al., 2012).

Description. The following description concerns the upper dentition of the referred specimen LACM 40463. Although the right and left maxillary fragments of this specimen are isolated, the two pieces of sandstone matrix in which the fossils are embedded fit well, indicating that they belonged to the same individual.

The base of P3 is surrounded by a welldefined cingulum (Figure 6.2). The main cusp of P3 has well-defined ridges on its anterior and posterior slopes, but no posterior accessory cusp is present (Figure 6.3). The base of P4 is also surrounded by a well-defined cingulum. The morphology of P4 paraconule and its surrounding portion is unknown because of breakage. The protocone of left P4 is rather small and low in height. The paracone of P4 is posterolabially directed, and the metastylar blade and carnassial notch are both well-developed.

The $\mathrm{M} 1$ is surrounded by a well-defined cingulum (Figure 6.1-2). The labial cingulum forms a clear ridge along the labial border of stylar shelf. In both the M1 and M2, the enamel surface along this ridge has a crenulated appearance. The paracone is only slightly larger (longer and taller) than the metacone (Figure 6.3), while both the paraconule and metaconule are represented as vestigial triangular projections. The slightly worn protocone is subequal in height to the paracone and is somewhat anteriorly directed such that it is at the same anteroposterior level as the paracone. The lingual cingulum of $\mathrm{M} 1$ is continuous around protocone; however, its anterior portion is very thin, and the posterior portion is not sufficiently inflated so as to form an additional cusp (i.e., "hypocone"). The stylar shelf is relatively wide and flat. The labial segment of preparacrista exhibits a slight anterior tilt.
TABLE 5. Dental dimensions of specimens referred to 'Miacis' hookwayi. Measurements in millimeters. Where applicable, the arithmetic mean of measurements for the right and left teeth is reported.

\begin{tabular}{lcc}
\hline & LACM 40463 & SDSNH 84969 \\
\hline P3L & 4.87 & \\
P3W & 2.63 & \\
P4L & $\sim 7.3$ & \\
P4W & $\sim 4.4$ & \\
M1L & 5.61 & \\
M1W & 7.86 & \\
M2L & 3.02 & \\
M2W & 5.20 & \\
p2L & & \\
p2W & & 3.70 \\
m1L & & 1.77 \\
m1W & & 6.20 \\
m1 trigonid length & & 4.02 \\
m2L & & 4.10 \\
m2W & & 4.08 \\
mandibular depth & & 3.14 \\
& & 7.80 \\
\hline
\end{tabular}

The preparacrista forms a continuous ridge with the centrocristae and postmetacrista. The parastylar region as a whole projects only moderately in the labial direction. The posterolabial margin of the tooth is more rounded than in the M1 of the substantially larger LACM 40450 (referred to 'Miacis' gracilis above).

The rather large M2 (Figure 6.1-6.3, Table 5) is separated from the M1 by a long distance lingually, presumably to accommodate the trigonid of a correspondingly large $\mathrm{m} 2$ (Figure 6.4). The M2 has a well-developed paracone, metacone, and protocone; surrounded by a well-defined cingulum as in M1. The stylar shelf is broad and flat. The labial segment of preparacrista is very small, and neither the paraconule nor the metaconule is identifiable. The lingual cingulum is continuous around the protocone. The paracone is only slightly taller than the metacone. A probable alveolus for M3 is seen on both the right and left maxillae.

Remarks. Stock (1934) named "Miacis (?) hookwayi" based solely on a left dentary fragment with m1 and m2 (holotype LACM CIT 1656; Figure 6.4) from the CIT locality 180 in the Sespe Formation, Ventura County, California. The specimen LACM 40463, representing the upper dentition and 

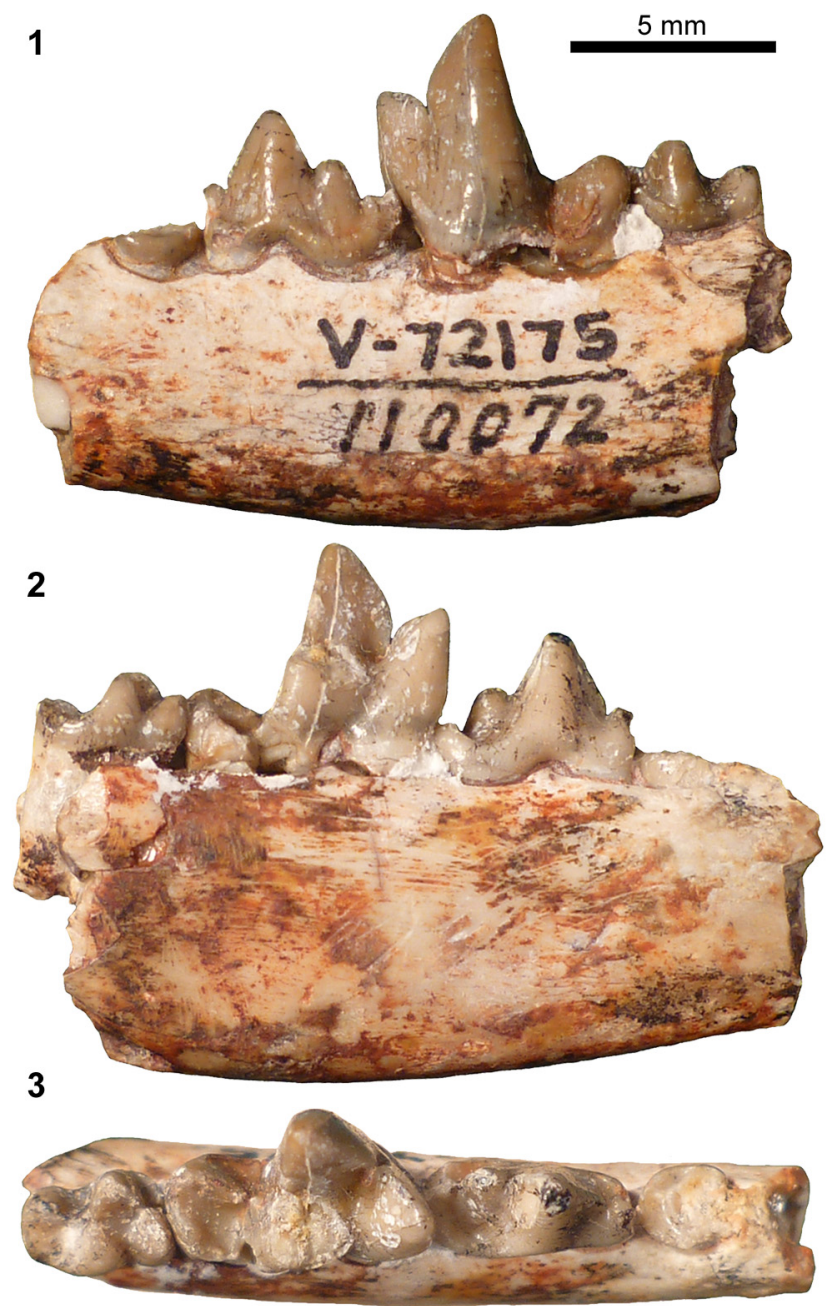

FIGURE 7. Undeterminate carnivoraform Genus A. Left dentary fragment with p4-m2 (UCMP 110072) in labial (1), lingual (2), and occlusal (3) views.

assigned to the same locality as the holotype, was apparently unknown (or unrecognized as belonging to ' $M$.' hookwayi) at the time of his original description. According to the information on the specimen card for LACM 40463, this specimen was identified by D.J. Golz as possibly ' $M$.' hookwayi, and a hand-written remark on the back side of the specimen card notes that the upper dentition "articulates well with type of Miacis (?) hookwayi," an observation that was confirmed by the author. SDSNH 84969, a dentary fragment from the Mission Valley Formation, is referred to ' $M$.' hookwayi based on the characteristically broad talonid of $\mathrm{m} 1$, relatively large $\mathrm{m} 2$, and the degrees of openness of $\mathrm{m} 1$ and $\mathrm{m} 2$ trigonids (Figure 6.5). A carnivoraform cranium SDSNH 56335 from locality 3757 of the Pomerado Conglomerate was previously reported as "cf. Miacis hookwayi" (Walsh, 1996) but is here referred to a separate taxon because its teeth are clearly distinct from those of LACM 40463 both in sizes and shapes (see undeterminate Genus B below). Because the dental material reported here does not support a particularly close affinity of 'Miacis' hookwayi with the genotypic species of Miacis, M. parvivorus (see Spaulding and Flynn, 2012, on the polyphyly of various species traditionally assigned to the genus Miacis), the generic classification of ' $M$.' hookwayi should be deemed questionable, as originally implied by Stock (1934).

\section{Carnivoraformes undet. Genus A} Figure 7

Referred Specimen. UCMP 110072, left dentary fragment with broken p3, p4-m2. 
TABLE 6. Dental dimensions of an undeterminate carnivoraform Genus A. Measurements in millimeters.

\begin{tabular}{lc}
\hline & UCMP 110072 \\
\hline $\mathrm{p} 4 \mathrm{~L}$ & 5.50 \\
$\mathrm{p} 4 \mathrm{~W}$ & 2.62 \\
$\mathrm{~m} 1 \mathrm{~L}$ & 6.36 \\
$\mathrm{~m} 1 \mathrm{~W}$ & 3.85 \\
$\mathrm{~m} 1$ trigonid length & 4.43 \\
$\mathrm{~m} 1$ trigonid height & 6.77 \\
$\mathrm{~m} 2 \mathrm{~L}$ & 3.74 \\
$\mathrm{~m} 2 \mathrm{~W}$ & 2.63 \\
mandibular depth & 7.19 \\
\hline
\end{tabular}

Locality. UCMP locality V72175, Thompson's Bonanza, Friars Formation, San Diego, San Diego County, California, USA.

Description. The referred specimen is characterized by a distinctive $\mathrm{p} 4$ that appears noticeably longer than tall (although slight wear is present on the apex and posterior slope of the main cuspid) and bears a prominent posterior accessory cuspid (Figure 7.1-3). The anterior cingulid of p4, while partly broken, seems to have been well developed. In comparison with other carnivoraforms reported here, the $\mathrm{m} 1$ of this specimen is similar in size to that of 'Miacis' hookwayi. However, the $\mathrm{m} 2$ of the former is approximately $30 \%$ smaller (in $\mathrm{m} 2 \mathrm{~L} \times$ $\mathrm{m} 2 \mathrm{~W}$ ) than that of ' $M$.' hookwayi (Table 6). The two taxa further differ in the width of $\mathrm{m} 1$ talonid relative to that of trigonid (wider in 'M.' hookwayi), the form of cristid obliqua of $\mathrm{m} 1$ (less trenchant in 'M.' hookwayi), and the openness of $\mathrm{m} 2$ trigonid (noticeably more closed in 'M.' hookwayi). UCMP 110072 differs from SDSNH 50599 (referred to Walshius pacificus above) in having a more robust $\mathrm{m} 1$ protoconid, a dorsoventrally shorter main cuspid of $\mathrm{p} 4$, and a more prominent $\mathrm{p} 4$ posterior accessory cuspid (Figures 2.3-5, 7.1-3).

Remarks. The referred specimen can be excluded from the Viverravidae because of the short $\mathrm{m} 2$ talonid. This specimen likely represents a new taxon of carnivoraform, but the presently available material is deemed insufficient for formal taxonomic description. Compared to middle-Eocene carnivoraforms that are known from outside southern California, the dental morphology of UCMP 110072 shows marked similarities with that of 'Miacis' hargeri from the Bridger Basin, Wyoming, particularly in the outline of relatively narrow talonid basin of $\mathrm{m} 1$, the degrees of openness of $\mathrm{m} 1$ and $\mathrm{m} 2$ trigonids, and the forms of individual trigonid cusps.
The p4 of UCMP 110072, however, is presumably more derived relative to those of earlier North American carnivoraforms (including ' $M$.' hargeri) in having a large posterior accessory cuspid (cf. Matthew, 1909, figure 15). In this latter respect, the specimen reported here resembles 'Miacis' washakius from the lower part of the Adobe Town Member of the Washakie Formation, Wyoming (possibly belonging to the Ui1a biochron; see McCarroll et al., 1996, and Gunnell et al., 2009), although the more anteriorly inclined $\mathrm{m} 1$ protoconid and the more closed trigonids of $\mathrm{m} 1$ and $\mathrm{m} 2$ distinguish UCMP 110072.

\section{Carnivoraformes undet. Genus B Figure 8}

Referred Specimen. SDSNH 56335, cranium with right and left P4-M2.

Locality. SDSNH locality 3757, Scripps Ranch North Site 57, Miramar Sandstone Member, Pomerado Conglomerate, San Diego, San Diego County, California, USA.

Tentatively Referred Specimens. LACM locality 5866, Sespe Formation, middle member, Simi Valley, Ventura County, California, USA: LACM 130826, right $\mathrm{m} 2$.

UCMP locality RV6830 (same locality as V6839), Laguna Riviera, Santiago Formation, member C, Carlsbad, San Diego County, California, USA: UCMP 314191, left m2.

UCMP locality V6839, Laguna Riviera 1, Santiago Formation, member C, Carlsbad, San Diego County, California, USA: UCMP 141385, left dentary with $\mathrm{p} 1-3, \mathrm{~m} 1$.

Description. The cranium, SDSNH 56335, is dorsoventrally crashed, and the anterior portion of rostrum is missing (Figure 8.3). Most of the cranial sutures are obscured by poor preservation. The infraorbital foramen is located above P3 and close to the anterior edge of P4. The posterior end of midline of palatine is more posteriorly located than the posterior margin of M2. No trace of M3, including its alveolus, can be discerned on the specimen. Because of extensive breakage, only limited observations can be made regarding the basicranial morphology (Figure 8.1). The ventral floor of basioccipital exhibits slight ventral deflection. No element is preserved that is recognizable as part of the auditory bullae; as such, presence or absence of ossified bullae cannot be determined. The petrosal promontorium shows some resemblance to that of Lycophocyon hutchisoni in the combination of somewhat globular posterolateral portion (surrounding fenestra cochlea) and rather flat antero- 


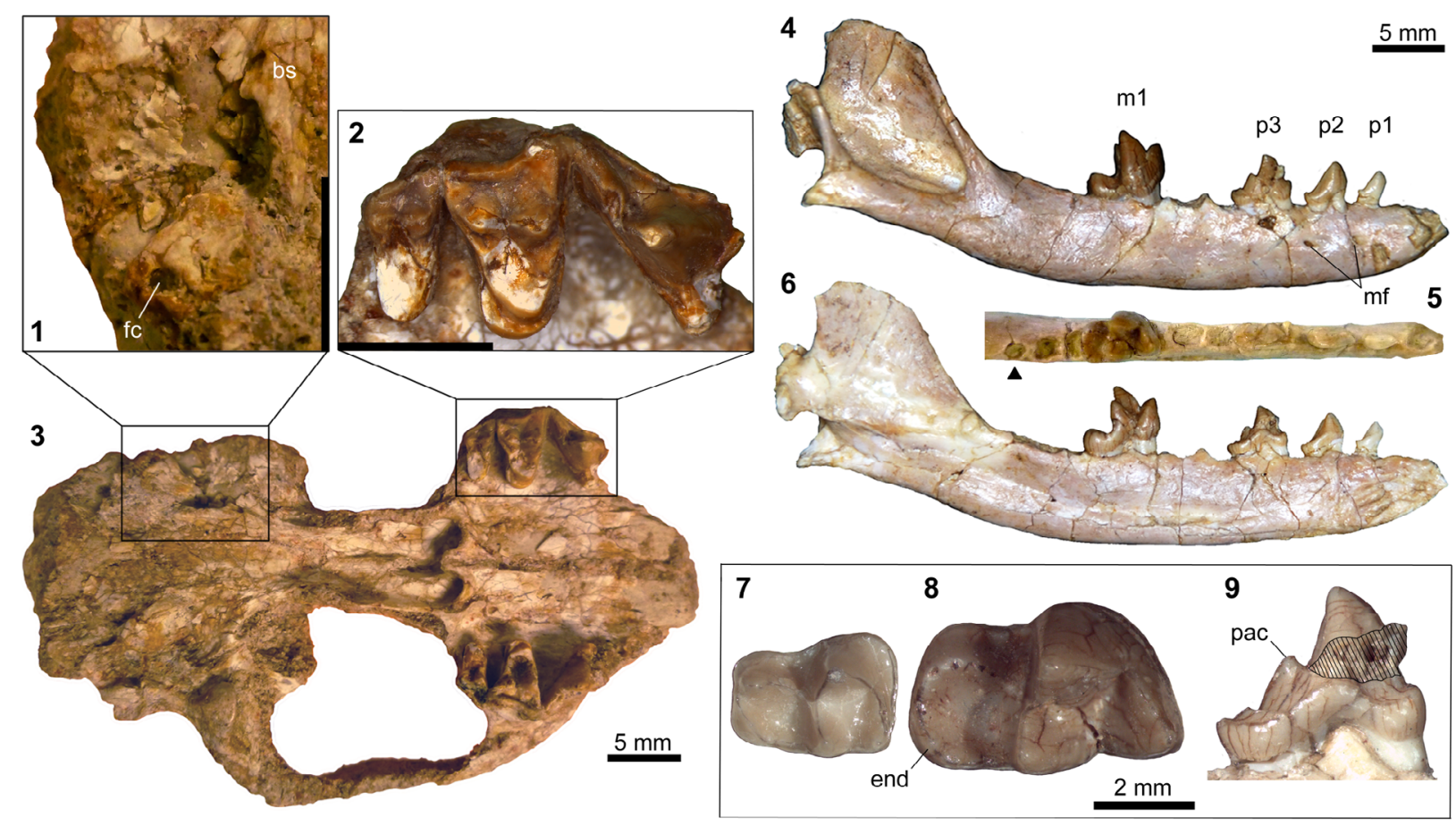

FIGURE 8. Undeterminate carnivoraform Genus B. SDSNH 56335, right middle-ear region (1), right P4-M2 (2) and cranium (3) in ventral view; UCMP 141385, left dentary in labial (4, inverted), occlusal (5), and lingual (6) views, left $\mathrm{m} 1$ in occlusal view (8), and left p3 in lingual view (9); UCMP 314191, left m2 in occlusal view (7). Black triangle in Figure 8.4 points to alveolus for $\mathrm{m} 3$. Scale bars for Figure 8.1 and 8.2 equal $5 \mathrm{~mm}$. Figure 8.4-8.6 at the same scale. Abbreviations: bs, basisphenoid; end, entoconid; fc, fenestra cochlea; mf, mental foramina; pac, posterior accessory cuspid.

medial portion that is less elongate than in Ceruttia sandiegoensis.

Among the upper premolars, only the P4 is known. The P4 of SDSNH 56335 (Figure 8.2) is less elongate than that of Walshius, and bears a preparacrista in contrast to the same tooth in Ceruttia. The orientation of paracone is similar to that in Ceruttia, showing less pronounced posterior tilt than in Walshius. The morphology of parastyle is obscured by breakage.

The M1 is distinguished from those of other carnivoraforms described in this paper by the more limited labial extension of the parastylar region (Figure 8.2). The margin of the broad stylar shelf labial to the metacone runs in the parasagittal direction, terminating at the rather angular posterolabial corner of the tooth; in this respect, the M1 of SDSNH 56335 resembles that of Ceruttia, but the tooth is anteroposteriorly more compressed in the latter (Figure 2.2). The labial segment of preparacrista runs in the straight labiolingual direction. The paracone is noticeably taller than the metacone. The paraconule is well-developed and considerably larger than the diminutive metaconule. The protocone of M1 is located close to the anterolin- gual margin of tooth, although a thin strip of lingual cingulum continues around the base of protocone. The lingual cingulum is expanded in the posterolingual direction, forming a crescentic shelf behind the protocone. This shelf, however, does not attain the same height as the protocone, and should not be regarded as a distinct cusp (i.e., "hypocone"). The anteroposterior asymmetry of lingual cingulum is more pronounced than in Ceruttia.

The M2 is rather large relative to the M1 (Figure 8.2), such that the ratio of M2L $\times M 2 W$ to $M 1 L x$ $\mathrm{M} 1 \mathrm{~W}$ is approximately 0.47 compared to $\sim 0.38$ in Ceruttia sandiegoensis (SDSNH 92504) and 0.39 in Walshius pacificus (SDSNH 46197). The labial projection of parastylar region is even more limited than in $\mathrm{M} 1$, rendering the two segments of preparacrista (one on the paracone and the other labial to the base of paracone) similar in length. The paracone and metacone are subequal in size and are not as reduced as in Ceruttia. The paraconule and metaconule cannot be clearly identified. The protocone lies close to the lingual margin of the tooth, contributing to the labiolingually broad trigon basin. In SDSNH 56335, the presence of considerable tooth wear on the lingual portion of right M2 
suggests its heavy involvement in mastication. No trace of M3 is discernible on SDSNH 56335.

The left dentary represented by UCMP 141385 is nearly complete except for the dorsal margin of coronoid process (Figure 8.4, 8.6). The mandible has a long and gracile appearance, with the mediolaterally thin horizontal ramus maintaining a roughly constant height along its length. In these respects and in size, UCMP 141385 resembles the basal arctoid Mustelavus priscus, known from the late Eocene (Chadronian NALMA) of North America. The anterior end of the medial surface of dentary bears shallow irregular grooves for the mandibular symphysis. The mental foramina are positioned below the anterior and posterior edges of $\mathrm{p} 2$. The ascending ramus rises at a relatively shallow angle with the horizontal ramus. The masseteric fossa is deep and clearly demarcated. The short angular process is directed posteriorly. The mandibular condyle is ventromedially twisted presumably through postmortem distortion.

The simple $\mathrm{p} 1$ and $\mathrm{p} 2$ are similar in form with respect to the lack of anterior cingulid, anteriorly tilted main cupid, and a small shelf formed by the posterior cingulid (Figure 8.4-6). In both the $\mathrm{p} 1$ and p2, a continuous ridge runs anteroposteriorly across the main cuspid. The p3 bears a small anterior cingulid and is marked by the presence of a pointed posterior accessory cuspid (Figure 8.9). The main cuspid of p3, of which an anterolingual portion is broken, is relatively low in height and is positioned well anterior to the midpoint of the length of tooth. A series of anteroposterior ridges runs along the main cuspid, the posterior accessory cuspid, and the small, shelf-like posterior cingulid of $\mathrm{p} 3$.

The $\mathrm{m} 1$ is characterized by the relatively low height of trigonid and the transversely broad talonid with a moderately deep basin (Figure 8.8). The paraconid and metaconid of $\mathrm{m} 1$ are subequal in size, and their apices are aligned with the lingual border of talonid. In part because of the posterior positioning of the metaconid relative to the protoconid, the $\mathrm{m} 1$ trigonid is more open than is typically seen in middle-Eocene carnivoraforms (and comparable to the degree seen in Procynodictis); the angle between the lines connecting the apices of paraconid, protoconid, and metaconid is approximately $69^{\circ}$. There is no cuspid that is recognizable as the hypoconulid. The posterolingual portion of the ridge that encircles the talonid basin has a somewhat crenulated appearance owing to the presence of very low entoconid and a similar-sized cuspulid anterior to it. This cuspulid is preceded by an even smaller raised ridge, which in turn follows a minute notch.

Although the $\mathrm{m} 2$ is not preserved in UCMP 141385 , the $\mathrm{m} 2$ alveoli suggest a tooth with precisely the size of UCMP 314191, which was collected from the same locality as the former specimen. This isolated $\mathrm{m} 2$ (Figure 8.7 ) is moderately large relative to the $\mathrm{m} 1$ of UCMP 143185 and closely resembles LACM 130826 from the Brea Canyon section of the Sespe Formation ("Miacis sp." of Kelly and Whistler, 1994, p. 6, figure 7). Both are characterized by the small size, low, relatively closed trigonid with reduced cuspids, broad talonid, and well-developed cingulid at the anterolabial corner of tooth. The paraconid and metaconid are subequal in size. The moderately deep talonid basin is labially bordered by a rather sharp cristid obliqua that descends steeply toward the posterolingual base of protoconid. In UCMP 141385 , the $\mathrm{m} 2$ is followed by a single alveolus for the $\mathrm{m} 3$ (Figure 8.5).

The width of the cranium measured between the labial margins of right and left M1 is approximately $25.4 \mathrm{~mm}$. Additional measurements are provided in Table 7.

Remarks. The cranium, dentary, and isolated lower teeth are here referred to the same genus based on their uniquely small size (being smaller than all other carnivoraforms known in the middle Eocene of southern California) and the relatively unreduced second molars. This referral, however, is provisional, and I refrain from describing this taxon as a new genus, pending discovery of associated upper and lower dentition and better-preserved upper dentition. In the Simi Valley Landfill site of Ventura County, the LACM locality 5866 is located roughly 70 meters above the level of CIT locality 202, which has yielded a variety of mammalian taxa that characterize the Brea Canyon local fauna (see Kelly et al., 1991, figure 2). The isolated $\mathrm{m} 2$ (LACM 130826) from the locality 5866 has previously been reported as a potentially new species of carnivoramorphan (Kelly et al., 1991; Kelly and Whistler, 1994). While the age of Miramar Sandstone Member of Pomerado Conglomerate-which has yielded the cranium SDSNH 56335-is poorly understood (Walsh, 1996), the common taxonomic identity of the specimen from Simi Valley and those from the Laguna Riviera local fauna is partly supported by the temporal proximity of the latter assemblage to the Brea Canyon local fauna (Walsh, 1996). 
TABLE 7. Dental dimensions of an undeterminate carnivoraform Genus B. Measurements in millimeters. Where applicable, the arithmetic mean of measurements for the right and left teeth is reported.

\begin{tabular}{|c|c|c|c|}
\hline & $\begin{array}{c}\text { SDSNH } \\
56335\end{array}$ & $\begin{array}{c}\text { UCMP } \\
141385\end{array}$ & $\begin{array}{l}\text { UCMP } \\
314191\end{array}$ \\
\hline P4L & $\sim 6.3$ & & \\
\hline P4W & $\sim 4.3$ & & \\
\hline M1L & 4.15 & & \\
\hline M1W & 6.39 & & \\
\hline M2L & 2.51 & & \\
\hline M2W & 5.03 & & \\
\hline $\mathrm{p} 1 \mathrm{~L}$ & & 2.02 & \\
\hline $\mathrm{p} 1 \mathrm{~W}$ & & 1.07 & \\
\hline p2L & & 3.11 & \\
\hline $\mathrm{p} 2 \mathrm{~W}$ & & 1.43 & \\
\hline p3L & & 4.22 & \\
\hline p3W & & 1.84 & \\
\hline $\mathrm{m} 1 \mathrm{~L}$ & & 5.50 & \\
\hline $\mathrm{m} 1 \mathrm{~W}$ & & 3.37 & \\
\hline $\mathrm{m} 1$ trigonid length & & 3.36 & \\
\hline $\mathrm{m} 1$ trigonid height & & 4.64 & \\
\hline $\mathrm{m} 2 \mathrm{~L}$ & & & 3.34 \\
\hline $\mathrm{m} 2 \mathrm{~W}$ & & & 2.34 \\
\hline mandibular depth & & 6.51 & \\
\hline
\end{tabular}

\section{DISCUSSION}

Figure 1.2 shows the stratigraphic and approximate temporal distributions of mammalian carnivores in the Uintan through the earliest Duchesnean NALMAs of southern California. With regard to San Diego County, updates to the faunal list of Walsh (1996, table 2) can be summarized as the following: 1) a total of 10 carnivoraform taxa (up from five in Walsh, 1996) are recognized, including Tapocyon dawsonae (Wesley and Flynn, 2003), Lycophocyon hutchisoni (Tomiya, 2011), and the two new genera named in this paper; 2) 'Miacis' hookwayi is no longer recognized in the Jeff's Discovery local fauna and the Eastview local fauna (belonging to member $\mathrm{C}$ of the Santiago Formation and Pomerado Conglomerate, respectively) but is present in the Mission Valley Formation.

More broadly, the middle-Eocene carnivorous mammals of the coastal southern California included a minimum of 11 carnivoraform species, the mesonychid Harpagolestes (considered by Szalay and Gould (1966) to have been a durophagous hypercarnivore), and at least four species of creodonts including: hyaenodontid Limnocyon sp. and an unnamed saber-toothed taxon (Wagner, 1999; "cf. Apataelurus" of Walsh, 1996, table 2) in the Jeff's Discovery local fauna; hyaenodontid Hyaenodon venturae from member $\mathrm{C}$ of the Santiago Formation and the middle member of the Sespe Formation; and Hyaenodon vetus from the middle member of the Sespe Formation.

Although the biostratigraphic utility of mammalian carnivores is limited by their general rarity in the fossil record, the updated record of carnivoraforms presented here is valuable for evaluating the recent re-interpretations of the ages of various middle-Eocene local faunas in southern California (Lander, 2011; Kelly et al., 2012). Of particular interest are: 1) the Tapo Canyon and Brea Canyon local faunas, which belong to the lower portion of middle member of the Sespe Formation in Ventura County; 2) vertebrate assemblages from the Mission Valley Formation of San Diego County (an ${ }^{40} \mathrm{Ar} /{ }^{39} \mathrm{Ar}$ age of $42.83 \pm 0.24 \mathrm{Ma}$ ago from possibly the upper portion of this formation was reported by Walsh et al., 1996, and was recalculated as 43.45 Ma ago by Lander, 2011); and 3) the Jeff's Discovery local fauna, which belongs to the lower portion of member $C$ of the Santiago Formation in San Diego County. Based on extensive magnetostratigraphic work in the Simi Valley area and the Uinta Basin, Prothero et al. (1996) assigned the Tapo Canyon and Brea Canyon local faunas to Chron C18r (41.3-40.1 Ma ago; see Kelly et al., 2012), making them perhaps 1.3 to 3.1 million years younger than the above-mentioned assemblages from San Diego County.

In a significant departure from this assessment, Lander (2011) considered the local faunas of Tapo Canyon, Brea Canyon, and Jeff's Discovery site to be correlatives of the White River Pocket assemblage of the Uinta Formation in view of shared taxonomic occurrences of protoreodontine agriochoerids. Lander's (2011) biostratigraphic scheme would tie these local faunas to the upper portion of Chron C20r at about $44 \mathrm{Ma}$ ago (cf. Kelly et al., 2012, figure 14). Yet another interpretation was advanced by Kelly et al. (2012), who assigned the Tapo Canyon and Brea Canyon local faunas to the lower half of Chron C19r (ca. 42.5-42.0 Ma ago) following a revised age (based heavily on occurrences of rodents) for the Duchesnean Simi Valley Landfill local fauna. Importantly, while the absolute ages of the local faunas proposed by Lander (2011) and Kelly et al. (2012) differ by approximately 1.5 to 2 million years, both of their proposals imply temporal proximity (greater than 
expected from Prothero et al.'s (1996) hypothesis in conjunction with the stratigraphic framework of Walsh et al., 1996) of the lower portion of middle member of the Sespe Formation, the lower portion of member $\mathrm{C}$ of the Santiago Formation, and the Mission Valley Formation, as was suspected by Walsh (1996). This point of agreement is further supported here by the stratigraphic distributions of Procynodictis progressus and 'Miacis' hookwayi (Figure 1.2).

In light of the current taxonomic knowledge, the Uintan through earliest-Duchesnean record of southern California is notable as it provides a more diverse carnivoramorphan assemblage than contemporaneous faunas from other regions in North America (cf. Gunnell et al., 2009, appendix; Friscia and Rasmussen, 2010, table 1). Of the 11 taxa recognized in Ventura and San Diego Counties (Figure 1.2), only two or three are known from elsewhere: Tapocyon robustus (from the Rocky Mountain region; Wesley and Flynn, 2003), 'Miacis' gracilis (from the Uinta Basin, Utah; Clark, 1939), and possibly Miocyon sp. (which is comparable in size to the unnamed species from Wyoming and Saskatchewan reported by Friscia and Rasmussen, 2010). While the absence of Walshius and unnamed carnivoraform Genus A outside southern California may well reflect the relatively poor fossil record for this time interval elsewhere (Ui1b of Gunnell et al., 2009), the occurrences of as many as six late-Uintan to earliest-Duchesnean taxa that are apparently endemic to the region (Ceruttia, 'Miacis' hookwayi, Lycophocyon, Procynodictis progressus, Tapocyon dawsonae, unnamed carnivoraform Genus B) are consistent with the elevated provinciality of North American mammalian faunas during this time (Lillegraven, 1979; Novacek and Lillegraven, 1979; Storer, 1989; Kirk and Williams, 2011). The evolutionary ecological underpinning of this long-recognized biogeographic pattern, however, is poorly understood (see Walsh, 1996; Townsend et al., 2010, and references therein).

So far as can be discerned from their dental morphology, most of the middle-Eocene carnivoraforms of southern California are small to mediumsized mesocarnivores (sensu Van Valkenburgh, 2007; see e.g., Tomiya, 2011). Although Tapocyon deviates from the rest of carnivoraforms in increased carnivory as indicated by its reduced $\mathrm{m} 1$ talonid basin and vestigial second molars (cf. Wesley and Flynn, 2003; Friscia et al., 2007; Friscia and Rasmussen, 2010), the unambiguous hypercarnivores in the regional mammalian fauna are not carnivoramorphans but creodonts, namely, the small $(\mathrm{m} 2 \mathrm{~L}=10.7 \mathrm{~mm}$ ) unnamed saber-toothed taxon in the Uintan Jeff's Discovery local fauna (Wagner, 1999) and two species of Hyaenodon known from the early Duchesnean. The high diversity of mammalian carnivores in the Uintan of southern California is in accord with the high richness of mammals as a whole from this time and place (NB: Although the current state of taxonomy makes it difficult to give a precise number here, over 50 species of non-carnivorous mammals have been reported for the late Uintan alone; cf. Walsh, 1996, Kelly, 1990; Kelly and Whistler, 1994; Walsh, 2000). In comparing well-sampled Cenozoic vertebrate fossil assemblages, Novacek and Lillegraven (1979) noted that favorable taphonomic conditions alone could not fully account for the remarkable mammalian diversity in the middle-Eocene record of San Diego area. Thus, the observed concordance between carnivore diversity and non-carnivore diversity might reflect a true ecological pattern, which would be in agreement with similar trends of broad correlation between mammalian predator and prey richness in modern communities (Croft, 2001) and in the Cenozoic fossil record (Van Valkenburgh and Janis, 1993).

\section{ACKNOWLEDGMENTS}

I am grateful to K.A. Randall and T.A. Deméré (SDSNH), S.A. MacLeod, V.R. Rhue, and X. Wang (LACM), M.A. Norrell and J. Galkin (AMNH), M.K. Brett-Surman (National Museum of Natural History, Washington, D.C.), D.L. Brinkman (Yale Peabody Museum of Natural History, New Haven), A.C. Henrici and A.R. Tabrum (CM), and K.D. Rose (Johns Hopkins University, Baltimore) for access to specimens under their care. I thank P.A. Holroyd, W.A. Clemens, and A.D. Barnosky (UCMP), M. Spaulding (AMNH), S.P. Zack (University of Arizona), and A.R. Friscia (University of California, Los Angeles) for helpful discussions, two anonymous reviewers for constructive comments on the manuscript, and J. Galkin and B.P. Kraatz (AMNH), E.B. Lander (Paleo Environmental Associates, Inc., Altadena), Z.J. Tseng (LACM), and K.C. Maguire, C.C. Maguire, and J.X. Maguire for hospitality during my museum visits. The Grants-in-Aid of Research program of the Berkeley Chapter of Sigma Xi, the UCMP Graduate Student Research Grant, and an NSF Doctoral Dissertation Improvement Grant (DEB-1011474) supported this research. The Annie M. Alexander Fellowship of UCMP supported the author while this study was conducted. This is UCMP contribution No. 2043. 


\section{REFERENCES}

Bryant, H.N. 1996. Explicitness, stability, and universality in the phylogenetic definition and usage of taxon names: a case study of the phylogenetic taxonomy of the Carnivora (Mammalia). Systematic Biology, 45:174-189.

Chow, M.-C. 1975. Some carnivores from the Eocene of China. Vertebrata PalAsiatica, 13:165-169.

Clark, J. 1939. Miacis gracilis, a new carnivore from the Uinta Eocene. Annals of the Carnegie Museum, 27:349-371.

Croft, D.A. 2001. Cenozoic environmental change in South America as indicated by mammalian body size distributions (cenograms). Diversity and Distributions, 7:271-287.

Dawson, M.R. 1980. Paleontology and geology of the Badwater Creek area, central Wyoming: Part 20, the late Eocene Creodonta and Carnivora. Annals of Carnegie Museum, 49:79-91.

Eizirik, E., Murphy, W.J., Koepfli, K.P., Johnson, W.E., Dragoo, J.W., Wayne, R.K., and O'Brien, S.J. 2010. Pattern and timing of diversification of the mammalian order Carnivora inferred from multiple nuclear gene sequences. Molecular Phylogenetics and Evolution, 56:49-63.

Flynn, J.J. and Galiano, H. 1982. Phylogeny of early Tertiary Carnivora, with a description of a new species of Protictis from the middle Eocene of northwestern Wyoming. American Museum Novitates, 2725:1-64.

Flynn, J.J., Finarelli, J.A., and Spaulding, M. 2010. Phylogeny of the Carnivora and Carnivoramorpha, and the use of the fossil record to enhance understanding of evolutionary transformations, p. 25-63. In Goswami, A. and Friscia, A.R. (eds.), Carnivoran Evolution: New Views on Phylogeny, Form, and Function. Cambridge University Press, Cambridge.

Friscia, A.R. and Rasmussen, D.T. 2010. Middle Eocene Carnivoramorpha of the Uinta Basin, Utah. Annals of Carnegie Museum, 79:51-63.

Friscia, A.R., Van Valkenburgh, B., and Biknevicius, A.R. 2007. An ecomorphological analysis of extant small carnivorans. Journal of Zoology, 272:82-100.

Gingerich, P.D. 1983. Systematics of early Eocene Miacidae (Mammalia, Carnivora) in the Clark's Fork Basin, Wyoming. University of Michigan Contributions from the Museum of Paleontology, 26:197-225.

Golz, D.J. and Lillegraven, J.A. 1977. Summary of known occurrences of terrestrial vertebrates from Eocene strata of southern California. University of Wyoming Contributions to Geology, 15:43-65.

Gunnell, G.F., Murphey, P.C., Stucky, R.K., Townsend, K.E.B., Robinson, P., Zonneveld, J.-P., and Bartels, W.S. 2009. Biostratigraphy and biochronology of the latest Wasatchian, Bridgerian, and Uintan North American Land Mammal "Ages." Museum of Northern Arizona Bulletin, 65:279-330.
Heinrich, R.E., Strait, S.G., and Houde, P. 2008. Earliest Eocene Miacidae (Mammalia: Carnivora) from northwestern Wyoming. Journal of Paleontology, 82:154162.

Kelly, T.S. 1990. Biostratigraphy of Uintan and Duchesnean land mammal assemblages from the middle member of the Sespe Formation, Simi Valley, California. Contributions in Science, Natural History Museum of Los Angeles County, 419:1-42.

Kelly, T.S. and Whistler, D.P. 1994. Additional Uintan and Duchesnean (middle and late Eocene) mammals from the Sespe Formation, Simi Valley, California. Contributions in Science, Natural History Museum of Los Angeles County, 439:1-29.

Kelly, T.S., Murphey, P.C., and Walsh, S.L. 2012. New records of small mammals from the middle Eocene Duchesne River Formation, Utah, and their implications for the Uintan-Duchesnean North American Land Mammal Age transition. Paludicola, 8:208-251.

Kelly, T.S., Lander, E.B., Whistler, D.P., Roeder, M.A., and Reynolds, R.E. 1991. Preliminary report on a paleontologic investigation of the lower and middle members, Sespe Formation, Simi Valley Landfill, Ventura County, California. PaleoBios, 13:1-13.

Kirk, E.C. and Williams, B.A. 2011. New adapiform primate of Old World affinities from the Devil's Graveyard Formation of Texas. Journal of Human Evolution, 61:156-168.

Lander, E.B. 2011. Stratigraphy, biostratigraphy, biochronology, geochronology, magnetostratigraphy, and plate tectonic history of the early middle Eocene to late early Miocene Sespe, Vaqueros, and lower Topanga Formations, east-central Santa Monica Mountains, Los Angeles County, southern California. Western Association of Vertebrate Paleontologists 2011 Annual Meeting Field Trip Volume and Guidebook. Paleo Environmental Associates, Altadena, California.

Lillegraven, J.A. 1979. A biogeographical problem involving comparisons of late Eocene terrestrial vertebrate faunas of western North America, p. 333-347. In Gray, J., and Boucot, A. J. (eds.), Historical Biogeography, Plate Tectonics, and the Changing Environment. Oregon State University Press, Corvallis, Oregon.

Matthew, W.D. 1909. The Carnivora and Insectivora of the Bridger Basin, middle Eocene. Memoirs of the American Museum of Natural History, 9:289-576.

McCarroll, S.M., Flynn, J.J., and Turnbull, W.D. 1996. Biostratigraphy and magnetostratigraphy of the Bridgerian-Uintan Washakie Formation, Washakie Basin, Wyoming. p. 25-39. In Prothero, D.R. and Emry, R.J. (eds.), The Terrestrial Eocene-Oligocene Transition in North America. Cambridge University Press, Cambridge. 
Mihlbachler, M.C. and Deméré, T.A. 2009. A new species of Brontotheriidae (Perissodactyla, Mammalia) from the Santiago Formation (Duchesnean, middle Eocene) of southern California. Proceedings of the San Diego Society of Natural History, 41:1-36.

Novacek, M.J. and Lillegraven, J.A. 1979. Terrestrial vertebrates from the later Eocene of San Diego County, California: a conspectus, p. 69-79. In Abbott, P.L. (ed.), Eocene Depositional Systems, San Diego, California. Pacific Section, Society of Economic Paleontologists and Mineralogists, Los Angeles.

Prothero, D.R. 2001. Magnetostratigraphic tests of sequence of stratigraphic correlations from the southern California Paleogene. Journal of Sedimentary Research, 71:526-536.

Prothero, D.R., Howard, J.L., and Dozier, T.H. 1996. Stratigraphy and paleomagnetism of the upper middle Eocene to lower Miocene (Uintan to Arikareean) Sespe Formation, Ventura County, California, p. 171188. In Prothero, D.R. and Emry, R.J. (eds.), The Terrestrial Eocene-Oligocene Transition in North America. Cambridge University Press, Cambridge.

Robinson, P., Gunnell, G.F., Walsh, S.L, Clyde, W.C., Storer, J.E., Stucky, R.K., Froehlich, D.J., Villafranca, I.F., and McKenna, M.C. 2004. Wasatchian through Duchesnean biochronology, p. 106-155. In Woodburne, M.O. (ed.), Late Cretaceous and Cenozoic mammals of North America: Biostratigraphy and Geochronology. Columbia University Press, New York.

Rohlf, F.J. 2006. tpsDig2, Version 2.10. Department of Ecology and Evolution, State University of New York at Stony Brook, Stony Brook, New York, USA. life.bio.sunysb.edu/morph/index.html

Rowe, T. 1988. Definition, diagnosis, and origin of Mammalia. Journal of Vertebrate Paleontology, 8:241-264.

Simpson, G.G. 1945. The principles of classification and a classification of mammals. Bulletin of the American Museum of Natural History, 85:1-350.

Spaulding, M. and Flynn, J.J. 2012. Phylogeny of the Carnivoramorpha: the impact of postcranial characters. Journal of Systematic Palaeontology, 10:653677.

Stock, C. 1934. New Creodonta from the Sespe Upper Eocene, California. Proceedings of the National Academy of Sciences of the United States of America, 20:423-427.

Stock, C. 1935. Plesiomiacis, a new creodont from the Sespe Upper Eocene, California. Proceedings of the National Academy of Sciences of the United States of America, 21:119-122.

Storer, J.E. 1989. Rodent faunal provinces, PaleoceneMiocene of North America. Natural History Museum of Los Angeles County, Science Series, 33:17-29.

Szalay, F.S. and Gould, S.J. 1966. Asiatic Mesonychidae (Mammalia, Condylarthra). Bulletin of the American Museum of Natural History, 132:127-174.
Teilhard de Chardin, P. 1914-1915. Les carnassiers des Phosphorites du Quercy. Annales de Paléontologie, 9:101-192.

Tomiya, S. 2011. A new basal caniform (Mammalia: Carnivora) from the middle Eocene of North America and remarks on the phylogeny of early carnivorans. PLoS ONE, 6:e24146.

Tomiya, S. 2012. Ecological aspects of the diversity dynamics of North American fossil mammals. Unpublished PhD Thesis, University of California, Berkeley, California, USA.

Townsend, K.E.B., Rasmussen, D.T., Murphey, P.C., and Evanoff, E. 2010. Middle Eocene habitat shifts in the North American western interior: a case study. Palaeogeography, Palaeoclimatology, Palaeoecology, 297:144-158.

Van Valen, L. 1966. Deltatheridia, a new order of mammals. Bulletin of the American Museum of Natural History, 132:1-126.

Van Valkenburgh, B. 2007. Déjà vu: the evolution of feeding morphologies in the Carnivora. Integrative and Comparative Biology, 47:147-163.

Van Valkenburgh, B. and Janis, C.M. 1993. Historical diversity patterns in North American large herbivores and carnivores, p. 330-340. In Ricklefs, R.E. and Schluter, D. (eds.), Species Diversity in Ecological Communities: Historical and Geographical Perspectives. University of Chicago Press, Chicago.

Wagner, H.M. 1999. A new saber-toothed carnivore from the middle Eocene of San Diego County, California. Journal of Vertebrate Paleontology, 3 (Suppl.):82A.

Walsh, S.L. 1996. Middle Eocene mammalian faunas of San Diego County, California, p. 75- 119. In Prothero, D.R. and Emry, R.J. (eds.), The Terrestrial EoceneOligocene Transition in North America. Cambridge University Press, Cambridge.

Walsh, S.L. 2000. Bunodont artiodactyls (Mammalia) from the Uintan (middle Eocene) of San Diego County, California. Proceedings of the San Diego Society of Natural History, 37:1-27.

Walsh, S.L., Prothero, D.R. and Lundquist, D.L. 1996. Stratigraphy and paleomagnetism of the middle Eocene Friars Formation and Poway Group, southwestern San Diego County, California, p. 120-154. In Prothero, D.R. and Emry, R.J. (eds.), The Terrestrial Eocene-Oligocene Transition in North America. Cambridge University Press, Cambridge.

Wang, X. and Tedford, R.H. 1994. Basicranial anatomy and phylogeny of primitive canids and closely related miacids (Carnivora: Mammalia). American Museum Novitates, 3092:1-34.

Wang, X. and Tedford, R.H. 1996. Canidae, p. 433-452. In Prothero, D.R. and Emry, R.J. (eds.), The Terrestrial Eocene-Oligocene Transition in North America. Cambridge University Press, Cambridge.

Wesley, G.D. and Flynn, J.J. 2003. A revision of Tapocyon (Carnivoramorpha), including analysis of the first cranial specimens and identification of a new species. Journal of Paleontology, 77:769-783. 
Wesley-Hunt, G.D. and Flynn, J.J. 2005. Phylogeny of the Carnivora: basal relationships among the Carnivoramorphans, and assessment of the position of 'Miacoidea' relative to Carnivora. Journal of Systematic Palaeontology, 3:1-28.

Westgate, J.W. 1990. Uintan land mammals (excluding rodents) from an estuarine facies of the Laredo Formation (middle Eocene, Claiborne Group) of Webb County, Texas. Journal of Paleontology, 64:454-468.
Wilson, K.L. 1972. Eocene and related geology of a portion of the San Luis Rey and Encinitas quadrangles, San Diego County, California. Unpublished MS Thesis, University of California, Riverside, Riverside, California, USA.

Wortman, J.L. and Matthew, W.D. 1899. The ancestry of certain members of the Canidae, the Viverridae, and Procyonidae. Bulletin of the American Museum of Natural History, 12:109-139. 